\title{
Yükseköğretim Kurumlarının Sürdürülebilir Rekabet Avantajı Elde Edebilmelerinde İlişkisel Pazarlamanın Rolü: Kaynak Avantajı Teorisi Bağlamında Nicel Bir İnceleme ${ }^{1,2}$
}

(Research Article)

Gaining Sustainable Competitive Advantage Through Relationship Marketing in Higher Education Institution: A Quantitative Analysis in the Resource Advantage Theory Context

Doi: 10.29023/alanyaakademik.872888

\section{Fatih ŞAHIN}

Dr. Öğr. Üyesi, Bandırma Onyedi Eylül Üniversitesi, Gönen Meslek Yüksekokulu, Yönetim ve Organizasyon Bölümü

fsahin@bandirma.edu.tr

Orcid No: 0000-0002-4760-4413

\section{Ercan TAŞKIN}

Prof. Dr., Kütahya Dumlupınar Üniversitesi, İIBF, Uluslararası Ticaret ve Finans Bölümü ercan.taskin@dpu.edu.tr

Orcid No: 0000-0001-8499-1013

Bu makaleye atıfta bulunmak için: Şahin, F. \& Taşkın, E. (2021). Yükseköğretim Kurumlarının Sürdürülebilir Rekabet Avantajı Elde Edebilmelerinde İlişkisel Pazarlamanın Rolü: Kaynak Avantajı Teorisi Bağlamında Nicel Bir İnceleme. Alanya Academic Review, Vol:5, No:3, pp. 1493-1516.

\section{Anahtar kelimeler: \\ Yükseköğretim \\ Pazarlamasi, \\ Ilişkisel Pazarlama, \\ Kaynak Avantajı \\ Teorisi, \\ Yetkinlikler, \\ Kaynaklar}

Makale Geliş Tarihi:

02.02.2021

Kabul Tarihi:

27.09.2021

\section{ÖZET}

Bu araştırmanın amacı güncel gelişmeler kapsamında yükseköğretim kurumlarının pazarlama faaliyetlerine yönelik ihtiyaçlarını ortaya koymak ve kaynak avantajı teorisi kapsamında iş birliklerinin başarısına ve yüksekögretim kurum performansina etki eden faktörleri yetkinlik temelli, kaynak temelli ve ilişsisel pazarlama bütünleşik modeli ile incelemektir. Yükseköğretim kurumlarının iş birliği başarısı ve kurum performansları üzerindeki etkisi olan faktörler kaynak avantajı teorisinin öne sürdüğ̈̈ bütünleşik model kullanılarak "Bölgesel Kalkınma Odaklı İhtisaslaşma" projesi kapsamında yer alan kurumlardan birisi olan Uşak Üniversitesi özelinde incelenmiştir. Araştırmada kullanılan veriler Uşak Üniversitesi'nde çalışmakta olan toplam 513 akademik ve idari personelden elde edilmiştir. Araştırmanın varsayımlarının analizinde yapısal eşitlik modellemesi kullanılmıştır. Elde edilen bulgulara göre uzun dönemli ilişkiler kapsamında oluşturulan iş birlikleri, ortaklık yetkinlikleri ve özgün kaynakların rekabette

\footnotetext{
${ }^{1} \mathrm{Bu}$ çalışma "Yükseköğretim Kurumlarında Güncel Gelişmeler ve İlişskisel Pazarlamanın Kaynak Avantajı Teorisi Bakış Açısıyla Yükseköğretim Kurumlarında Etkileri: Uşak Üniversitesi” adlı doktora tezinden üretilmiştir.

${ }^{2} \mathrm{Bu}$ araştırma ve araştırmada kullanılan veri ile uygulanacak yöntemin etik değerlere uygun olduğu Uşak Üniversitesi Sosyal ve Beşerî Bilimler Bilimsel Araştırma ve Yayın etiği Kurulu tarafından uygun görülmüştür.
} 
konum avantajı elde edebilmede önemli bir rolü olduğu sonucuna ulaşılmıștır.

Keywords:

Higher Education
Marketing,
Relationship
Marketing,
Resource Advantage
Theory,
Competences,
Resources

\begin{abstract}
The aim of this study is to reveal the needs of higher education institutions for marketing activities within the scope of current developments and to examine the factors affecting the success of cooperation and higher education institution performance within the scope of resource advantage theory with an integrated model of competency-based, resource-based and relational marketing. The factors that have an effect on the cooperation success of higher education institutions and their performance have been examined with the integrated model proposed within the scope of resource advantage theory in the context of Uşak University that one of the members of "Regional Development Oriented Mission Differentiation and Specialization Programme". The data used in this study was obtained from a total of 513 academic and administrative staff working at Uşak University. Structural equation modeling was employed to analyze the assumptions of the research. The findings show that the cooperation, partnership competencies, and original resources created within the scope of long-term relationships play a significant role in gaining a competitive position advantage.
\end{abstract}

\section{GİRIŞ̧}

Akademia'lar Eflatun ve Aristo'nun dini ve politik hiçbir baskı altında olmaksızın felsefe alanında fikir alışverişi gerçekleştirdikleri faaliyet ve toplanma alanlarından yola çıkarak günümüze üniversite (universitas) adını alarak evrensel ölçekte bağımsız ve tüzel bir kişiliğe sahip kurumlar olarak ulaşmışlardır. Bu kapsamda, yükseköğretim kurumları insanlık tarihinin en eski kurumlarından birisi olarak kabul edilmektedir. Yükseköğretim kurumları ait oldukları toplumları etkileyen ve etkilenen (Siemens ve Matheos, 2012: 4) yapılarıyla açık bir sistem olmaları sayesinde günümüze ulaştığını söyleyebilmek mümkündür. Böylelikle süreç içerisinde zaman zaman karşılaştıkları birçok sorunu çözerek günümüze kadar ulaşabilmeyi başarabilmiştir. Toplum ve yükseköğretim kurumları arasındaki bu etkileşimsel ilişki, yükseköğretim kurumlarına içinde bulunulan dönemin gerektirdiği çerçevede toplumun ihtiyaçlarını karşılamak üzere bazı görevler yüklenilmesine neden olmuştur. Fakat tarihsel süreç içerisinde toplumsal değişimi fark edememeleri veya göz ardı etmeleri, zaman zaman kapalı bir siteme dönüşmelerine neden olmuş, beklentileri karşılamayan yükseköğretim kurumlarının toplum tarafından "fildişi kuleleri" olarak isimlendirilmesine neden olmuştur. Tarım toplumundan, endüstri toplumuna ve günümüz bilgi toplumuna geçişte değişime ayak uydurmak, toplumun taleplerini karşılayabilmek amacıyla üniversiteler değişim sürecini sürekli bir şekilde devam ettirmek zorunda kalmışlardır. Dolayısıyla orta çağdan günümüze kadar geçen zaman diliminde ve hatta günümüzün konuşulmakta olan gelecek nesil üniversitelerine geçişte yaşanan sosyal değişimler yükseköğretim kurumlarını önemli bir şekilde etkilemektedir. Özellikle değişimlerin neden olduğu belirsizliklerin siyaset yapıcılar, kanun düzenleyiciler ve kurumları ilgilendirdiği gibi günümüzde içinde bulunduğu toplum kavramı küresel olarak ele alınan üniversiteleri de yakından ilgilendirmektedir (Scott, 2006: 1). 
Yükseköğretim kurumlarına toplumun yükledikleri görevlerin zaman içerisindeki değişimi, ulusal ve uluslararası alanda finansman, nitelikli akademisyen ve öğrenciler ile iş birliği firsatları için rekabetin giderek arttı̆̆ı ortamda, yükseköğretim kurumlarının paydaşları ile ilişki ağları oluşturmaları, geliştirmeleri ve sürdürebilmeleri için sahip oldukları ilişki ağları içerisinde yer alan paydaşları için belirli bir değere sahip teklifler sunabilmeleri önem taşımaya başlamıştır. Özellikle de pazarlama faaliyetlerinin kâr amacı güden işletmeler için olduğu kadar kâr amacı gütmeyen işletmeler için de bir zorunluluk (Kotler ve Levy, 1969: 15) haline geldiği anlaşılmaya başlanmıştır. Yükseköğretim kurumları faaliyetlerinin etkin, etkili ve ekonomik bir şekilde yönetilmesi (OECD, 2011: 5), çeşitli paydaşların fonksiyon ve görevlerinin tanımlanmasında yeni kamu yönetimi anlayışının küresel olarak kabul görmesi ve kamu yönetimini pazar yönlülük ile tanıştırmıştır (OECD, 2011: 5). Bu gelişmelerin yanı sıra büyük bir kısmı vatandaşların vergilerinden elde edilen, kıt devlet kaynaklarının önemli bir kısmı günümüzde yükseköğretim ve araştırma faaliyetlerine ayrılması sonucu yükseköğretim kurumlarının devlete ve toplumun daha geniş kısmına hesap verebilirlik ihtiyacını ortaya çıkmıştır (OECD, 2011: 4).

Bu kapsamda bu çalışmada, Uşak Üniversitesi (UÜ)'sinin Uşak Organize Sanayi Bölgesinin (UOSB), Uşak Karma Organize Sanayi Bölgesinin (UKOSB), Uşak Ticaret ve Sanayi Odası (UTSO) ve Türkiye İŞKUR arasındaki iş birliği ilişkisel pazarlama kapsamında ele alınarak, kaynak avantajı kuramı çerçevesinde bu ilişkilerin rekabette konum avantajı, ortaklık performansı ve üniversite performansı üzerindeki etkisi incelenmiştir. Bununla birlikte kaynak avantajı teorisine yönelik nicel araştırmaların kısıtlı olduğu anlaşılmaktadır (Wittmann vd., 2009; Yalçın, 2010). Wittmann vd. (2009)'ın iki kâr amacı güden işletme arasındaki ilişkinin finansal performans üzerine etkisini ve hem de geliştirilen kaynak avantajı teorisine nicel bir kanıt ortaya koyabilmek üzere kullandıkları model temel alınarak kamu yükseköğretim kurumlarının çıktılarının farklılı̆̆ı da göz önünde tutularak uyarlanarak araştırma modelinde kullanılmıştır. $\mathrm{Bu}$ araştırmanın yüksseköğretim kurumlarının pazarlanması literatürüne katkı sağlayacağı, ayrıca kamu yükseköğretim kurumlarının kâr amacı gütmeyen işletme kategorisinde değerlendirilmesi nedeniyle kaynak avantajı teorisi ile ilgili alan yazınına da katkı sağlayacağı değerlendirilmektedir.

\section{KAVRAMSAL ÇERÇEVE}

Küreselleşme, teknolojik ve ekonomik belirsizlikler, genişleme ve teknolojik becerileri yüksek öğrencilerin kendi aralarında ve içeriklerle etkileşime girebilmeleri yükseköğretim kurumlarına farklı firsatlar sunmaktadır. Bu ve buna benzer birçok gelişimin bütüncül etkisi akademilerin eğitim, araştırma ve topluma katkı sağlama şekillerinden toplumun onlardan beklentileri ile nasıl ortak bir amaç çerçevesinde kesişebileceği hususuna kadar yeniden üzerinde düşünülmesi ve yapılandırılması ihtiyacını ortaya çıkartmaktadır (Siemens ve Matheos, 2012: 4). Üniversiteler her dönemde değişimin eksenini oluşturan kurumlar olarak kabul edilmiştir (Bell, 1973: 20). Bu kapsamda ele alındığında ise değişen ve gelişen yeni ekonomik ve teknolojik ortamda yeni toplumsal taleplerin karşılanabilmesi için üniversitelerin örgütsel esnekliklerini koruyabilmeleri önemlidir (Scott, 2006: 1). Wissema (2009) ve Arimoto (2014) toplumların günümüz yükseköğretim kurumlarından eğitim ve araştırma faaliyetlerine ek olarak bilginin açığa çıkartılması ve toplumsal hizmet gibi beklentileri bulunduğuna dikkat çekmektedirler. Yaşanan bu toplumsal değişimin anlaşılabilmesinde post-endüstriyel dönem özelliklerinin anlaşılabilmesinin önemli olduğu değerlendirilmektedir. Post-endüstriyel kavramını ortaya atan Bell (1973)'e göre post- 
endüstriyel dönemin özellikleri beş başlık altında ele alınabilmektedir. $\mathrm{Bu}$ dönemin ilk özelliklerinden birisi ekonomik yapıda gerçekleşmiş, temel olarak mal üretiminden hizmet ekonomisine geçiş yaşanmaktadır. Fourastié (1949) ve Bell (1973)'e göre özellikle üçüncül sektör faaliyetlerindeki (hizmet sektörü) artış ekonominin gelişmişlik seviyesi hakkında önemli bilgiler sağlamaktadır. Fialová (2014: 135)'ya göre post-endüstriyel döneme geçiş yapmış olan ekonomilerin \%80'ini üçüncül sektör faaliyetleri oluşturmaktadır. Postendüstriyel dönemin ikinci özelliği ise bu dönemde mesleki ve teknik sınıfın önemi giderek daha fazla artmaktadır. Özellikle üretimin sembolü olan fabrikaların yerini bilgi tabanlı ürünlerin üretim ve dağıtımında kullanılan veri tabanları, bilgi ağları ve araçlarının öneminin artması mesleki ve teknik sınıf çalışanlarının genel istihdam içerisindeki önemini nitel ve nicel olarak arttırmıştır (Masuda, 1980: 31). Bu dönemin üçüncü özelliği ise üretimin ekseninin bilgiye doğru dönüşmeye başlaması, teorik bilgiye olan ihtiyacın artmasıdır (Siemens ve Matheos, 2012: 8). Duderstadt (2000: 14)'e göre bu gelişmeler günümüz toplumunun yükseköğretim kurumlarına olan ihtiyacını daha da arttırmaktadır. Yükseköğretim kurumlarının ve ulusların patent ve yenilikçilik alanındaki araştırmaları, uluslararası iş birlikleri sayesinde arttırılmaya çalışılmaktadır (OECD, 2015). Post-endüstriyel dönemin dördüncü özelliği geleceğe odaklılık olarak tanımlanmaktadır. Bu kapsamda ele alınan sorunlar, özellikle toplumun hızlı değişime uyum sağlamaya ve bu değişim sonucu meydana gelebilecek zararlı sonuçlarla başa çıkılmasına yönelik sorunlar değerlendirilmektedir (Bell, 1973: 27; Masuda, 1980: 33). Son olarak bilgi teknolojilerinin karar alma sistemlerinde kullanılması yer almaktadır. Bu kapsamda oldukça karmaşık ve insan zihni ile çözülmesi kapasite ve zaman açısından oldukça güç olan bazı sayısal ve sözel verilerin teknolojik gelişmeler ile çözümlenebilmesi mümkün olması sonucu yaşanan değişim ele alınmaktadır. Günümüzde kurumsal kaynak planlaması ve buna bağlı olarak bilgi iletişim teknolojisi uzmanlarının istihdam içerisindeki oranlarındaki artış ekonomik gelişim için önemli olduğu kadar (OECD, 2015: 43) yetişmiş işgücüne olan ihtiyacı da arttırmıştır.

Post-endüstriyel dönemde yaşanan bu gelişmeler ise yükseköğretim kurumları açısından bazı çözümlenmesi gereken sorunları da beraberinde getirmektedir. Wissema (2009: 17) yükseköğretim kurumalarını değişime zorlayan konuları çeşitli açılardan ele alınmıştır. Bu konulardan ilki uluslararası kamuoyu tarafindan yükseköğretim kurumlarına eğitim-öğretim, araştırma ve toplumsal katkı görevleri yüklenmiştir. UNESCO (1998)'nun yükseköğretim kurumlarına yönelik olarak gerçekleştirdiği konferansta; yükseköğretim kurumlarının misyonları bir bütün olarak toplumun sürdürülebilir kalkınması ve ilerlemesine katkıda bulunmak için eğitim, öğretim ve araştırma faaliyetlerini yürütmek şeklinde tanımlanmaktadır. Benzer şekilde Türkiye'de de yükseköğretim kurumlarının görevlerine göz attığımızda benzer bir eğilim görülmektedir. Yükseköğretim kurumlarında gerçekleşen bir diğer gelişme ise öğrenci sayılarındaki aşırı artışlar birlikte ortaya çıkan kitleselleşme hareketidir. Bu gelişme ile eğitim ticarileşmeye başlamış ve akademisyenlerin öğrenciler ile geçirdikleri zaman azalmıştır (Wissema, 2009: 17). Türkiye'deki üniversite sayılarındaki artışla ile öğrenci sayılarında kitleselleşmenin etkili olduğu anlaşılmaktadır (Şahin ve Taşkın, 2018: 72). Bu eğilim neticesinde devlet bütçesinden desteklenen kamu üniversitelerinin genel bütçe içerisindeki harcamalarında meydana gelen aşırı artış neticesinde, yükseköğretim kurumlarının kemer sıkma politikalarına ve çeşitli devlet düzenlemelerine maruz kalmalarına yol açmıştır (Wissema, 2009: 17). Diğer taraftan yükseköğretim kurumlarının paydaşlarının beklentilerinde artış yaşanması ve büyük bir kısmı vatandaşlardan elde edilen vergilerden meydana gelen devlet bütçesinde yükseköğretim kurumları ve araştırma faaliyetlerine ciddi 
miktarlarda kaynaklar ayrılması sonucu yükseköğretim kurumlarının paydaşlarına yönelik hesap verebilir olması ihtiyacını ortaya çıkartmıştır (OECD, 2011: 4). Yeni kamu yönetimi anlayışının gelişimi ile yükseköğretim kurumlarının ve onların çeşitli paydaşlarının görev ve fonksiyon tanımlarının değişimine rehberlik etmektedir. Bu gelişim ile kamu yönetimi pazar odaklılık ile tanışmış ve üç "E" olarak ifade edilebilecek olan etkin, etkili ve ekonomik olma yönetimin performansının ölçümünde ön plana çıkmıştır (OECD, 2011: 5). Yeni kamu yönetimi anlayışının temel bileşenleri karar verme süreçlerini ademi merkeziyetçi hale getirmek, yatay yapılaşmaya geçiş yapmak, pazar tipi mekanizmaların ön plana çıkışı ve bununla birlikte özel sektör yönetim araçları ile en iyi uygulama kavramları olarak sıralanabilmektedir. Tüm bu gelişmeler birkaç benzerlik dışında yönetsel açıdan yükseköğretim kurumlarının geleneksel yapıdan tamamen farklı bir yapıya dönüşmesini sağlamış ve girişimcilik unsurunun ön plana çıkmasını sağlamıştır (OECD, 2011: 5). Kamuda yaşanan yönetim anlayışında gerçekleşen bu değişim ile yükseköğretim kurumları daha fazla rekabet edebilir hale gelmiştir (Enders, 2006: 149). Türkiye'de ise Yükseköğretim Kurulu'nun 2016-2020 Yılları Stratejik Planında yer alan "Toplumun ve ekonominin ihtiyaçlarına duyarlı, paydaşlarıyla etkileşim içerisinde olan, ürettiği bilgiyi ürüne, teknolojiye ve hizmete dönüştüren, akademik, idari ve mali açıdan özerk üniversite modeli çerçevesinde küresel ölçekte rekabetçi bir yükseköğretim sistemine ulaşılması hedefi”" (YÖK, 2015) ifadesinde rekabetçi yükseköğretim kurumlarına vurguda bulunulmuştur.

Teknolojide yaşanan hızlı gelişim yenilikçi ürünlerin hızla tüketilmesi ve yaşam döngüsünün kısalması dolayısıyla araştırma ve geliştirme faaliyetlerinin öneminin artmasına neden olmuştur. Özellikle iki veya daha fazla bilim dalını kapsayan disiplinler arası bilimsel araştırmaların önemi giderek artmaktadır (Wissema, 2009: 19). Bu açıdan yükseköğretim kurumlarının örgütsel yapıları, yönetim şekillerindeki esneklik derecesi ile özellikle çeşitli paydaşları ile kurmuş olduğu ilişkiler ön plana çıkmaktadır. Türkiye'deki disiplinler arası bilimsel araştırmalar alanındaki çalışmaların ise diğer ülkelere kıyasla bu alandaki çalışmaların oldukça kısıtlığg olduğu düşünülmektedir (Şahin ve Taşkın, 2018: 80).

$\mathrm{Bu}$ gelişmelerin yanı sıra ulusların, araştırma geliştirme faaliyetlerine yönelik yatırımlardan elde edilen getirilerin yüksek olduğunu fark etmesi ile bu alanlara ayırdıkları bütçeleri arttırmaya başlamışlardır. Yenilikçi ürün ve hizmetlerin hızla tüketilmesinin sonucu araştırma geliştirme maliyetlerinde artışa neden olmuştur (Wissema, 2009: 19). OECD ülkelerinde araştırma geliştirme faaliyetlerine ayrılan bütçenin GSMH içerisindeki payının \%2,5 iken bu miktar Türkiye'de yaklaşık \%1'dir (Şahin ve Taşkın, 2018: 81). Araştırma geliştirme faaliyetlerine olan ilginin bu denli artışı NASA, SpaceX, CERN gibi uzmanlaşmış araştırma enstitülerinin ortaya çıkmasına neden olmuştur (Wissema, 2009). Bu gelişmeler, teorik bilginin ve araştırma geliştirme faaliyetlerinin merkezi olan yükseköğretim kurumlarının yeni ekonomik faaliyetlerinin vazgeçilmez bir unsuru olarak ele alınmasını sağlamıştır. Yenilikçi ürün ve hizmetlere olan talebin artışı sonucu bazı endüstriyel araştırma geliştirme kuruluşları temel bilimler alanında gerçekleştirilen araştırmalara duyduğu ihtiyaç nedeniyle mevcut araştırma programlarını durdurmak zorunda kalmışlardır. $\mathrm{Bu}$ ve buna benzer sorunların çözümlenebilmesinin yolunun ise akademik kuruluşlar ile iş birliğinden geçtiği anlaşılmaya başlanmıştır (Wissema, 2009: 21). Bunlara ek olarak girişimcilik faaliyetleri yükselen bir trend içerisine girmiş ve küresel kapsamda bu faaliyetlere yönelik destekler artış göstermiş, girişimcilik faaliyetlerinin ulusal ve uluslararası ekonomide önemli bir rol oynadığı anlaşılmaya başlanmıştır (Wissema, 2009). Türkiye'de de girişimcilik faaliyetleri önemli düzeyde artış göstermektedir (Kalkınma, 2015: 23). Bu açıdan değerlendirildiğinde, toplum 
tarafından yükseköğretim kurumlarına geleceğin girişimcilerini yeterli bilgi donanımı ile yetiştirmeleri, ulusal ve uluslararası ekonominin gelişimine katkı sağlama görevi yüklenmiştir.

Küresel kapsamda gerçekleşen bu gelişmeler çerçevesinde Türkiye'deki yükseköğretim kurumlarının işleyişine yönelik çeşitli uygulamaları da gündeme getirmiştir. $\mathrm{Bu}$ uygulamalardan bir tanesi "Bölgesel Kalkınma Odaklı İhtisaslaşma" projesi olarak adlandırılmaktadır. Sağlık ve çevre alanında Düzce Üniversitesi, tarım ve jeotermal alanında Kırşehir Ahi Evran Üniversitesi, hayvancılık alanında Burdur Mehmet Akif Ersoy Üniversitesi, tarım ve havza bazlı kalkınma alanında Bingöl Üniversitesi, tekstil, dericilik ve seramik alanında ise Uşak Üniversitesi (UÜ) bölgesel kalkınma odaklı misyon farklılaşması projesinin pilot yükseköğretim kurumları olarak belirlenmiştir (YÖK, 2016).

UÜ sanayi iş birliği kapsamında incelendiğinde çeşitli iş birlikleri bulunduğu anlaşılmaktadır. $\mathrm{Bu}$ iş birliklerinden UÜ ve Uşak Organize Sanayi Bölgesi (UOSB) yanı sıra Uşak Deri Karma Organize Sanayi Bölgesi (UKOSB), Uşak Ticaret ve Sanayi Odası (UTSO) ve Türkiye İŞKUR'un yer aldığı eğitim iş birliği araştırma kapsamında incelenmiştir. Bu iş birliğinin ilk temelleri 2012 yilında UÜ ile UOSB arasinda imzalanan bir protokol ile atılmıştır. İşbirliğinin amacı UOSB'de faaliyet gösteren işletmeler ile UÜ'nün arasında uyum sağlamaya yönelik olarak eğitim çabalarına yön verecek esasların tespiti, teorik bilgi ile pratik uygulamalar arasında bütünlük sağlamak, araştırma faaliyetlerinin toplumsal yaşamda uygulamaya dönüştürülebilmesi ile iş başı eğitim faaliyetlerinin yaygınlaştırılması ve öğrencilerin çalışma hayatına hazırlanması olarak belirlenmiştir. 2014 yılında ise bu iş birliğinin kapsamı eğitim alanında genişletilmiş ve UÜ ve UOSB'nin yanı sıra UKOSB, UTSO ve Türkiye İŞKUR'un da katılımıyla uygulama alanı genişletilmiştir. Daha sonra ise YÖK (2016)'nun kararıyla bu iş birliğinin tekstil, dericilik ve seramik alanına yönelik genişletilmiştir.

Küresel ve yerel çerçevede gerçekleşen bu gelişmeler ekseninde değerlendirildiğinde Türkiye'deki yükseköğretim kurumlarının gelecekte ulusal ve uluslararası alanda daha fazla rekabetçi olmalarını destekleyici birtakım politikalar izlendiği gözlemlenmektedir. Yükseköğretim kurumlarının sağladıkları hizmetlerin çeşitlendirilmesi ve rekabette öne çıkabilmelerinde özellikle farklılaşmanın önemli bir rol oynadığı, bunun gerçekleştirilebilmesi için ise öncelikli olarak yükseköğretim kurumlarının içinde bulundukları toplumun özelliklerini gözetmelerinin önemi anlaşılmaya başlamışlardır. Dolayısıyla yükseköğretim kurumları ile ilgili makro ve mikro stratejik planlarda bölgesel kalkınma odaklılı̆ga yer vermeye çalıştıkları gözlemlenmektedir. Diğer taraftan devlet tarafından finanse edilen devlet üniversitelerinin bütçe planlamasında kuruluş tarihleri ile öğrenci sayıları dikkate alınmakta iken bütçe planlamalarında sağladıkları değer ve hizmetlerin temel alınacağı bunun ise rekabeti arttıracağı düşünülmektedir (A.A., 2016).

Bu kapsamda bu araştırmanın konusu UÜ'si eğitim iş birliği özelinde yükseköğretim kurumlarının sahip oldukları işbirliklerinin başarısı açısından ilişkisel pazarlama yaklaşımı, kaynak temelli teori ve yetkinlik temelli teorisi bütünleşik bir model olarak ele alınarak kaynak avantajı teorisi çerçevesinde yükseköğretim kurumlarının performanslarının arttırılmasında etkili olan faktörleri inceleyerek hem de bu teorik yapının nicel olarak kar amacı gütmeyen bir örgüt olarak kamu yükseköğretim kurumlarında araştırmaktır. Diğer taraftan yükseköğretim kurumlarının pazarlanması hususunda yükseköğretim kurumlarının alanındaki yönetici, pazarlamacı ve araştırmacılara katkı sağlamayı amaçlamaktadır. 


\section{LITERATÜR}

$\mathrm{Bu}$ alanda gerçekleştirilen araştırmalarda (Lambe vd., 2002), başarılı iş birliklerin sonucunu rekabet avantajı elde edebilmede önemli bir yere sahip olan özgün kaynakların geliştirilebilmesinin mümkün olduğu öne sürülmektedir. Bununla birlikte Lambe vd. (2002: 142)'ye göre iş birliğinin başarısının yalnızca finansal göstergeler temeline odaklandığı bu sebeple diğer önemli göstergelerin göz ardı edildiği öne sürülmektedir. İşbirliklerinin başarısının ölçümünde finansal göstergeler dışında farklı çıktıların değerlendirilmesinin literatüre katkı sağlayacağı anlaşılmaktadır (Lambe vd., 2002: 154). Diğer taraftan ilişkisel pazarlama kapsamında güven bağlılık teorisini geliştiren Morgan ve Hunt (1994), aslında kâr amacı gütsün veya gütmesin tüm işletmelerin pazarlama faaliyetlerine ihtiyaç duyduğunu vurgulamışlardır. İşletmeler tarafından yürütülen pazarlama faaliyetlerinin ilişki kurma, geliştirme ve sürdürülmesi esasına dayandığı düşünülerek işletmelerin sahip oldukları ilişki türleri gruplandırılmış ve ilişkisel pazarlama alanındaki çalışmaların kamu yararı güden iş birliklerinde de yürütülmesinin önemine değinilmektedir (Morgan ve Hunt, 1994: 20). Kâr amacı güden işletmelerin oluşturduğu bir iş birliğinin incelendiği araştırmada (Wittmann vd., 2009) yetkinlik temelli faktörler, kaynak temelli faktörler ile ilişkisel pazarlama faktörleri bütünleşik bir model içerisinde ilk kez kaynak avantaj1 teorisi çerçevesinde değerlendirilmiştir. Wittmann vd. (2009: 753), ulaşılan sonucun ilgili literatürü desteklemediği fakat bunun Morgan ve Hunt (1994)'in da dikkat çektiği üzere birçok iş birliği çeşidi bulunması nedeniyle bu iş birlikleri üzerinde de bu araştırma modelinin uygulanarak sonuçların karşılaştırılmasına ihtiyaç duyulduğunu belirtmişlerdir. Kaynak avantajı teorisinin özellikle yetkinlik temelli, kaynak temelli ve ilişkisel pazarlama faktörlerini bütünleşik bir şekilde ele alarak hem bu faktörlerin hem de bunların çıktı olarak işletme performansı üzerindeki katkısını incelemeye çalışmaktadır. Diğer taraftan, pazarlama faaliyetlerinin kamu kurumlarının (Caruana vd., 1999), yükseköğretim kurumlarının performansı üzerinde olumlu etkisi olduğu (Caruana vd., 1998; Niculescu vd., 2013) bu alanda gerçekleştirilen nicel araştırmalardan da anlaşılmaktadır.

Yetkinlik temelli faktörler olarak değerlendirilen üst yönetim desteği ve ortaklık yetkinliklerinin işletme başarısı üzerinde önemli bir etkiye sahip olan özgün kaynakların geliştirilmesinde katkı olduğu değerlendirilmektedir (Lambe vd., 2002). Kaynak temelli yaklaşım açısından tamamlayıcı kaynaklar ve özgün kaynaklar iş birliği başarısında önemli bir yere sahiptir. Bununla birlikte iş birliği ile ilgili literatürde ilişkisel pazarlama faktörleri sosyal sermaye (Coleman, 1988; Ahuja, 2000), ilişkisel sermaye (Kale vd., 2000), ilişki sermayesi (Sarkar vd., 2001) olarak adlandırılmıştır. Falkenberg (1996)'e göre rakipler tarafından taklidinin zor ve işletmelere özgün olan bu tür davranışsal varlıklarının fiziksel varlıklarından daha önemli olduğunu ve bunların yalnızca işletme içinde değil, işletme dışında da bulunduğunu vurgulamaktadır. Dolayısıyla işletmelerin değer oluşturmaya yönelik ilişki ağları oluşturma sürecinde, çevre analizlerini gerçekleştirirken sahip oldukları ilişkileri göz önünde bulundurmalarının büyük bir öneme sahip olduğuna değinilmektedir. Bu çerçevede Jap (1999) tarafından gerçekleştirilen bir araştırmada, karşılıklı iş birliği çabalarında tamamlayıcı yetkinliklerin, koordinasyon faaliyetleri ile özgün yatırımların finansal performans ve rekabet avantajı üzerinde etkisi bulunduğu öne sürülmektedir. Diğer taraftan, kaynak avantajı teorisi (Hunt ve Morgan, 1995, 1997) iş birliği başarısını yetkinlik temelli, kaynak temelli ve ilişkisel faktörler yardımıyla açıklamaya çalışmaktadır. Kaynak avantajı teorisi kaynak temelli işletme bakışını benimser, yetkinlikleri en önemli kaynaklar arasında değerlendirerek, ilişkisel pazarlama için teorik bir temel hazırlar ve iş birliklerinin 
ilişkisel kaynakların bir çeşidi olduğunu savunur. Buna ek olarak pazar konumunda rekabet avantajı elde edilmesi sonucu üstün işletme performansı sağlanacağı savunulmaktadır.

\subsection{Kaynak Temelli Bakış}

Kaynaklar işletmelerin hedef pazarlar için belli bir değere sahip pazar tekliflerini etkin ve etkili bir şekilde oluşturabilmesini sağlayan somut ve soyut özelliğe sahip varlıklar olarak açıklanmaktadır (Hunt, 1995: 11). Kaynak temelli teori çerçevesinde işletme kaynakları finansal, fiziksel, yasal, beşerî, örgütsel, bilgi niteliğinde (pazar odaklı) ve ilişkisel (ilişkisel odaklı) olarak sınıflandırılmıştır (J. Barney, 1991: 100; Hunt ve Duhan, 2002: 100). İşletme kaynakları heterojen ve hareketsiz olarak kabul edilmektedir. J. Barney (1991: 105)'ye göre sürdürülebilir rekabet avantajı sağlayan kaynakların dört temel özelliği değerli olması, nadir olması, taklit edilmesinin zor olması, ikame edilemez olmasıdır.

Hunt ve Derozier (2004: 11)'e göre işletme verimliliğinin arttırılması ve rekabet avantajı elde edilebilmesi için kaynaklardan en iyi şekilde faydalanılması gerekir. J. Barney (1991: 100)'e göre kaynak temelli teori iki temel odak noktası çerçevesinde işletmelerin sürdürülebilir rekabet avantajı üzerindeki etkilerini araştırmaktadır. Bunlardan ilki, bir endüstride yer alan işletmelerin kontrol edebildikleri kaynaklar açısından heterojen olabilecekleri varsayılmaktadır. İkinci olarak ise, kaynakların işletme içerisinde tam hareketsiz olmayabileceğini ve uzun süre kaynakların heterojenliğinin sürdürülemeyeceğini varsaymaktadır. İşletmelerin sahip olduğu kaynakların hareketsiz olma özelliğine sahip olması özellikle başarılı rakiplerin aynı kaynakları elde etme çabalarına rağmen kaynaklar heterojen olma özelliklerini zaman içerisinde devam ettirebilir (Hunt ve Lambe, 2000: 20).

Yalnızca heterojen, hareketsiz, rakipler arasında asimetrik bir şekilde dağılmış olan kaynakların, rekabet avantajı ve üstün finansal performans sağlayabileceği savunulmaktadır (Hunt ve Lambe, 2000: 21). Heterojenlik ve hareketsizlik tek başına sürdürülebilir rekabet avantajı sağlamak için yeterli değildir. Sürdürülebilirlik sağlanabilmesi için rakiplerin rekabet avantajı sağlayan kaynakları geliştirmeyi veya bu kaynakların stratejik ikamesini zor görmeleri gerekir (J. Barney, 1991: 107). Taklit edilememesi ise ancak, özel tarihsel geçmişe dayalı şartlar, nedensel belirsiz kaynaklar ve sosyal kompleks kaynaklar ile sağlanabilir (Hunt ve Lambe, 2000: 21). J. B. Barney (1992: 45) sosyal kompleks kaynaklar işletmedeki bireyler veya grupların birbiri arasındaki ilişkiler sonucu sahip oldukları ve işletmenin bunlar doğrultusunda örgütün stratejilerini tasarlama, belirleme ve uygulamasında etkili olan faktörlerdir. Tek başına fiziksel teknolojik kaynaklar ele alındığında rakipler tarafından kolay taklit edilebilir özelliğe sahiptirler. Fakat fiziksel teknolojinin kullanılması için genellikle sosyal komplekslik de dâhil olur. Böylelikle fiziksel teknolojiden faydalanmak rekabet avantajının sürdürülebilmesinde kullanılabilir (Hunt ve Lambe, 2000: 21). Kaynaklar geniş kapsamlı bir tanıma sahiptir ve strateji arasındaki ilişki işletmenin başarısı ve büyümesini açıklamada yeterli bir model oluşturamamaktadır (Lewis ve Gregory, 1996: 146). Bu yüzden işletme stratejisinin bütüncül bir içsel açıklamasının yapılabilmesi için tamamlayıcı, dinamik, içsel bir işletme teorisine ihtiyaç duyulmaktadır. Bu tanıma uygun olan teori ise yetkinlik temelli teoridir (Hunt ve Lambe, 2000: 22).

\subsection{Yetkinlik Temelli Bakış}

Yetkinlik temelli teori işletmelerin içsel kaynaklarına odaklanan bir stratejik yaklaşımdır. Kaynak temelli teorinin ise işletmelerin kaynaklarından faydalanmak için geliştirdikleri stratejilerin nasıl özgün yapılara dönüştürülebileceğini açıklamaya çalışan yetkinlik temelli 
teoriyi tamamladığı kabul edilmektedir (Rumelt, 1984: 22). Ayırt edici yetkinlik kavramı Selznick (1957)'nin çalışmalarından yola çıkılarak ortaya atılmıştır ve işletmelerin en önemli özgün stratejik kaynaklarından birisi olduğu düşünülmektedir. Bu kapsamda Prahalad ve Hamel (1990: 81)'e göre işletmelere, ürünlerin, stratejik iş birimlerinin ve yetkinliklerin bütünü ele alınarak bakılmalıdır. Temel yetkinliklerin çıktıları ürünlerin değerinin arttırılmasına, yeni pazarlara girilebilmesine ve müşterinin fayda algısı üzerinde olumlu bir etkisi vardır. Rakiplerin taklit edebilmelerini zorlaştırır. Temel yetkinlikler, fiziksel varlıkların tersine kullanım sonucu tükenmez aksine kullanıldıkça ve paylaşıldıkça zenginleşir. Temel yetkinlikler açısından insan unsuru örgütlerin en kritik varlıklarıdır (Prahalad ve Hamel, 1990: 90). Lado vd. (1992: 82)'ya göre yetkinlik temelli teori, kaynak temelli teorinin mantıksal bir uzantısıdır. Bu kapsamda ele alındığında yönetimsel yetkinlikler, strateji odaklılık, kaynak temelli, çıktı temelli ve değişim temelli yetkinlikler birbirleri arasında yakından ilişkilidir. İşletmenin sahip olduğu bu yetkinlikler çevreye iyi uyum sağlamak amacıyla aldığ 1 kararlar ile zaman içerisinde gelişebileceği gibi diğer taraftan bilinçli ve sistematik bir şekilde işletmenin yöneticileri tarafindan tercih ettikleri stratejik seçim ve faaliyetler sonucu da şekillenebilmektedir (Lado vd., 1992: 78). Rekabet avantaj1 konumu elde etme ve sürdürme yöneticilerin işletmenin taklidi zor özgün yetkinlikleri desteklemesi ve geliştirmesine odaklanmalarını gerekmektedir (Lado vd., 1992: 88). Hamel ve Prahalad (1994: 157)'a göre işletmeler birer kaynak portföyü (teknik, finansal, insan, vb.) olarak ele alınmalıdır. İşletme stratejisinin yalnızca mevcut kaynakların (yetkinliklerin) ve mevcut firsatların uyumlaştırılmasından daha çok gelecekte endüstrinin durumunu öngörmek ve mevcut yetkinliklerden bu kapsamda faydalanmaya odaklanması gerektiği düşünülmektedir (Hamel ve Prahalad, 1994: 159). Bu çerçevede yetenekler, işletmelerin en önemli varlıkları olduğu değerlendirilmektedir (Sanchez vd., 1996: 7).

\section{3. İlişkisel Pazarlama}

İlişkisel pazarlama, işletme süreçlerinin iyileştirilmesi, geliştirilmesi ve pazarlama faaliyetlerinde stratejik paydaşları bütünleşik bir şekilde ele alarak (Shani ve Chalasani, 1992: 43), yine bu paydaşlar arasındaki etkileşimi de göz önünde bulundurmaktadır (Sheth ve Parvatiyar, 1995: 399). Bu ilişki ağları içerisinde gerçekleşen etkileşimler ilişkisel pazarlamanın temelini oluşturan en önemli unsurlardan birisidir (Parvatiyar ve Sheth, 1992: 238). Sahip olunan ilişkiler arasındaki etkileşimler bütünleşik bir şekilde ele değerlendirilirken tarafların planlarının birbiri ile ortak bir noktada buluştuğu varsayılır ve böylelikle taraflar arasında yakın ekonomik iş birliğine dayalı bir yapı ortaya konulmaya çalışılmaktadır. $\mathrm{Bu}$ sebeple işletmelerin rekabet ve çatışmadan ortak iş birliklerine, paydaşlarından bağımsız seçimlerden karşılıklı bağlılığa yönelik bir değişime ihtiyaç duyduklarını göstermektedir (Sheth ve Parvatiyar, 1995: 399). İlişkisel pazarlama alanındaki araştırmacılar işletmelerin müşterileri için yüksek değer oluşturabilmenin yolunun karşılıklı iş birliği olduğuna inanmaktadırlar (Solomon, 1992: 26; Morgan ve Hunt, 1994: 20). Rekabetin doğasının yıkıcı olduğu ve ortak iş birliğinin ise yapıcı bir özelliğe sahip olduğu genel görüş halini almaya başlamıştır (Shaker ve Basem, 2010: 548).

Günümüz anti-tröst yasalarının ise neoklasik bir yaklaşımla, işletmelerin birbirinden bağımsız olduğu, işletmeler arası iş birliklerine karşı ve denge ekonomisine dayanan bir yaklaşım çerçevesinde şekillendiği düşünülmektedir (Hunt ve Arnett, 2001: 15). İşletmelerin birbirinden bağımsız olarak ele alınması her alanda pazarlama aktörlerinin kendi çıkarlarını korunmasını sağlayacak olan kendi değişim yönlü ortağını seçme özgürlüğü sunmaktadır 
(Sheth ve Parvatiyar, 1995: 399). Bu yapısal çevre içerisinde işletmeler satın alma maliyetlerini en aza indirebilmek için pazarlık ve teklif verme yöntemlerini kullanılırlar (Sheth ve Parvatiyar, 1995: 399). İşletmelerin birbirinden bağımsız olmasının, kendi çıkarlarının korunması ve maliyetlerini en aza indirebilmek için pazarlık ve teklif verme yöntemlerinin kullanılması gibi konular iktisatçılar tarafından da eleştirilmiştir (Shaker ve Basem, 2010: 549). Bu eleştirilerin nedeni değişim yönlü yaklaşımın aslında işletme maliyetleri ve etkinliklerine olumsuz yönde etkisinden kaynaklanmaktadır (Grönroos, 1994: 8; Sheth ve Parvatiyar, 1995: 400).

İlişkisel pazarlama alanında çalışmalar gerçekleştiren araştırmacılar işletmelerin birbirlerine olan karşılıklı bağlılığı sayesinde; işlem maliyetleri ve yönetsel faaliyet maliyetlerini, değişim yönlü pazarlama odaklı faaliyet gösteren işletmelere kıyasla daha düşük miktarlarda tutabilmeleri nedeniyle ilişsisel pazarlama odaklı işletmelerin pazara daha yüksek kalitede ürün sunabileceklerini öne sürmektedirler (Grönroos, 1994: 8). Değer zinciri içerisinde yer alan aktörler arasındaki ortaklık ve karşılıklı bağlılık sayesinde, işletmeler daha düşük maliyetle daha yüksek kalite elde edebilmektedirler (Sheth ve Parvatiyar, 1995: 400). Bunların yanı sıra başarılı bir ilişkisel pazarlama stratejisi sonucu elde edilebilecek faydalar Hunt vd. (2006: 77), pazar rekabet avantaj1 geliştirme (Hunt, 1997; Smith ve Barclay, 1997; Day, 2000), rakiplerine kiyasla üstün finansal performans (Kalwani ve Narayandas, 1995; Boles vd., 2000; Hunt, 2000; Walter ve Gemünden, 2000; Weber, 2000), müşteri memnuniyeti düzeyinin arttırılması (Schellhase vd., 2000), örgütsel öğrenme (Selnes ve Sallis, 2003), ortakların sadakat eğilimlerinin artması (Jap, 2001; Verhoef, 2003), ortaklar tarafından kabul görme (Kumar vd., 1992), belirsizliklerin azaltılması (Achrol ve Stern, 1988) olarak sıralanmaktadır. Buna ek olarak ilişkisel pazarlama stratejisinin başarısında (Hunt vd., 2006: 78), ilişkisel faktörler, kaynak faktörleri, yetkinlik faktörleri, içsel pazarlama faktörleri, bilgi teknolojileri faktörleri, pazar teklifi faktörleri, tarihsel faktörler, kamu politikası faktörleri önemli bir rol oynamaktadır.

\subsection{Kaynak Avantajı Teorisi}

Kaynak avantajı teorisi çerçevesinde rekabet dinamik ve sürekli gelişen bir şekilde ele alınmaktadır (Hunt ve Morgan, 1996; Hunt, 1997c). Kaynak avantajı teorisi aynı zamanda pazar temelli ve komut ekonomileri verimlilikleri arasındaki farklılığın açıklanmasına da katk1 sağlamakta (Hunt, 1995; Hunt ve Morgan, 1997), yol bağlılığ1 teorisi ile uygunluk göstermekte (Hunt ve Morgan, 1996), içsel büyüme modeli için teorik bir altyapı sunmaktadır (Hunt, 1997). Bunların yanı sıra kaynak avantajı teorisi sosyal kurumlar açısından güvenin arttırılmasının verimlilik üzerinde nasıl bir etki oluşturacağını açıklamaya çalışmaktadır (Hunt ve Lambe, 2000: 33). Bu kapsamda, kaynak avantaj1 teorisine göre rekabet, işletmelerin kaynaklar üzerinde rakiplerine kıyasla avantaj elde edebilmek ve böylelikle üstün finansal performans elde etmek amaciyla sürekli bir mücadele süreci olarak ele alınmaktadır (Hunt vd., 2006: 76).

Kaynak avantajı teorisinde işletmenin bazı pazar bölümlerine etkin ve etkili bir pazar teklifi oluşturabilmesini mümkün kılan kaynaklar somut ve soyut olmak üzere iki grup altında ele alınmaktadır (J. Barney, 1991: 101). Soyut kaynaklar arasında değerlendirilen ilişkilerin, ilişkisel kaynaklara dönüşebilmesi için işletmelerin hedef pazara etkin ve/veya etkili bir şekilde pazar teklifi hazırlamalarına katkı sağlaması gerektiği düşünülmektedir. İşletmeler diğer işletmelerle stratejik iş birliğine girmeleri sonucunda, tamamlayıcı ve/veya kendine özgü bir kaynak mülkiyeti veya kaynakları geliştirici bir etki yaratması durumunda ilişki 
içerine girerler. Benzer şekilde işletmelerin kar amaçsız işletmelerle ilişkisinde eğer müşteriye sunulan pazar teklifinin değerinde bir artış sağlanabiliyorsa ancak bu şekilde etkili olabilecektir (Hunt vd., 2006: 76). Lambe vd. (2002) tarafından gerçekleştirilen bir araştırmaya göre yetkinlik temelli faktörler olan üst yönetim desteği ve ortaklık yetkinliklerinin, kaynak temelli faktörler kapsamında ele alınan özgün kaynaklar aracılığı ile işletme başarısı üzerinde dolaylı bir etkiye sahip olduğu sonucuna ulaşmışlardır. $\mathrm{Bu}$ çerçevede özgün kaynakların bu sebeple iş birliği başarısına ulaşmada önemli bir aracı değişken olduğu sonucuna ulaşmışlardır. İş birliği ile ilgili literatürde ilişkisel pazarlama faktörleri sosyal sermaye (Coleman, 1988; Ahuja, 2000), ilişkisel sermaye (Kale vd., 2000), ilişki sermayesi (Sarkar vd., 2001) olarak adlandırılmıştır. Bu kaynaklar, iş birliği içerisindeki işletmelerin birlikte daha kolay hareket edebilmelerini sağlamakta ve iş birliği içinde yer alan bir işletmeler sahip oldukları önemli kaynaklarını paylaşır ve iş birliğinin başarısı için çaba sarf ederler (Lambe vd., 2002).

Bu kapsamda kaynak avantajı teorisi (Hunt ve Morgan, 1996, 1997; Hunt, 2000) iş birliği başarısında, kaynak temelli işletme bakışını benimser, işletme yetkinlikleri en önemli kaynaklar arasında görür, ilişkisel pazarlama için teorik bir temel hazırlar ve iş birliklerinin ilişkisel kaynakların bir çeşidi olduğunu savunmaktadır. Son olarak pazar konumunda rekabet avantajının üstün işletme performansı elde edilmesinde önemli bir rolü olduğunu savunmaktadır. Jap (1999) tarafından gerçekleştirilen araştırmaya göre karşılıklı iş birliği çabalarında tamamlayıcı yetkinlikler, koordinasyon faaliyetleri ile özgün yatırımlar finansal performans ve rekabet avantajı üzerinde olumlu bir etkiye sahiptir. Wittmann vd. (2009) tarafından kaynak avantajı teorisinin varsayımlarını incelemeye yönelik gerçekleştirilen çalışmada yetkinlik temelli bakış, kaynak temelli bakış ve ilişkisel pazarlama bakış açılarının birbirlerini tamamlayan ve her bir bakış açsısının rekabet avantajını ayrı ayrı yeterli düzeyde açıklayabilme yeteneğine sahip olduğu sonucuna ulaşılmıştır. Bunun yanı sıra konum avantajı ortaklık performansı üzerinde aracı değişken rolü oynamaktadır.

\section{METODOLOJI}

Araştırma modelinin analizinde kullanılan veriler Uşak Üniversitesi'nde görev yapan akademik ve idari personel arasından basit rastgele örnekleme yöntemi kullanılarak toplanılmıştır. Veri toplama aracı olarak kullanılan çevrimiçi anket formu kullanılmıştır. Verilerin toplanmasında survey.com internet sayfası kullanılmıştır. Şekillendirilen anket formuna katılımcıların ulaşabilmesi amacıyla internet bağlantı adresi oluşturulmuş ve kurum çalışanlarının elektronik posta adreslerinin bulunduğu bir liste oluşturularak katılımcı adaylarına gönderilmiştir. Elde edilen veriler Spss 23 ve Amos 23 programları ile analiz edilmiştir. Araştırmanın ve araştırmada kullanılacak veri ile uygulanacak yöntemin etik değerlere uygun olduğuna dair karar Uşak Üniversitesi Sosyal ve Beşerî Bilimler Bilimsel Araştırma ve Yayın etiği Kurulu'nun 13.10.2016 tarih ve E.30125 sayılı yazısıyla bildirilmiştir.

\subsection{Araştırmanın Modeli}

Jap (1999) tarafından kaynak temelli bakış modeli nicel olarak incelenmiş ve daha sonra Hunt vd. (2002) kaynak temelli bakış açısının yanı sıra, yetkinlik temelli bakış ve ilişkisel pazarlama bakış açısını da kullanarak iş birliği başarısı ve rekabet avantajının etkisini açıklamaya yönelik teorik bir model önermişler ve bu model Wittmann vd. (2009) tarafından nicel olarak incelenmiştir. $\mathrm{Bu}$ araştırmalara ek olarak Niculescu vd. (2013)'un pazar 
odaklılığın üniversite performansı üzerindeki etkisini ölçmeye yönelik kullandığı model uyarlanarak Şekil 2'de yer alan araştırma modeli ve hipotezleri oluşturulmuştur.

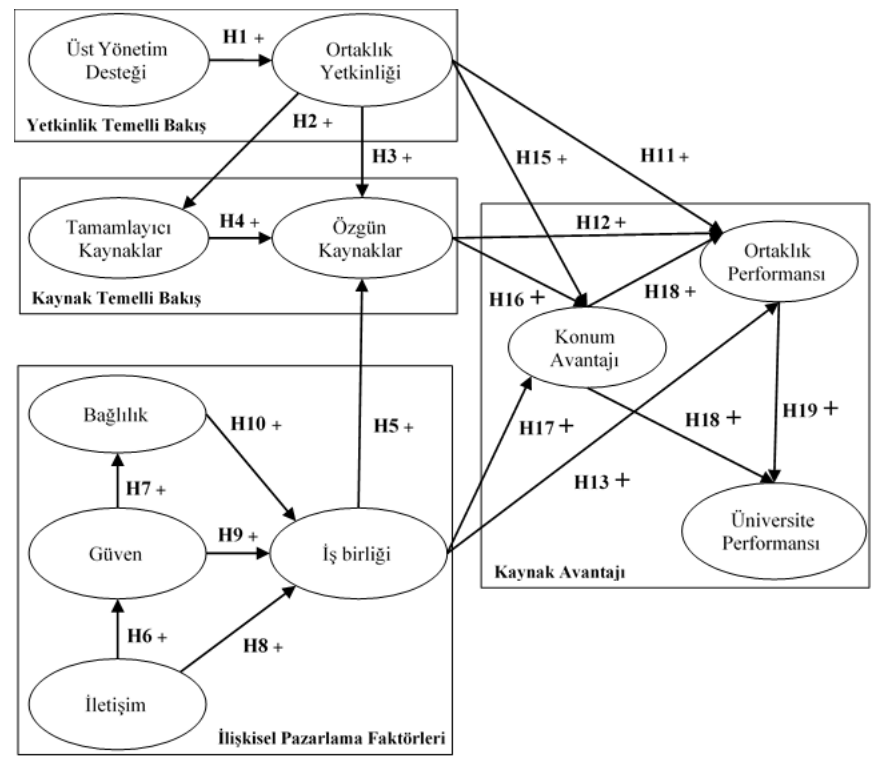

Şekil 2. Araştırma Modeli ve Hipotezleri

\section{2. Ölçekler}

Araştırma kapsamında kullanılan ankette 4 temel ölçek (yetkinlik temelli, kaynak temelli, ilişkisel pazarlama ve kaynak avantajı) ve bu ölçekler ile ilgili 11 alt boyut kullanılmış, bu alt boyutların ölçümüne yönelik olarak ise toplam 60 anket sorusundan faydalanılmıştır. Araştırma modelinde yer alan değişkenlerin ölçümlenmesinde kullanılan ölçekler sırasıyla; yetkinlik temelli bakış boyutunu ölçmeye yönelik olarak kullanılan 3 alt boyut olan üst yönetim desteği (UYD) ile ilgili 5 madde; ortaklık yetkinliği (OY) ile ilgili 6 madde Lambe vd. (2002)'un çalışmasından uyarlanmıştır. Kaynak temelli bakışın ölçümüne yönelik 2 alt boyut kullanılmış; tamamlayıcı kaynaklar (TK) ölçeğine yönelik 3 madde ve özgün kaynaklar (OK) ölçeğine yönelik 6 madde Lambe vd. (2002)'ın çalışmasından uyarlanmıştır. İlişkisel pazarlama boyutunun ölçümünde güven (G) ile ilgili 5 madde, iletişim (I) ile ilgili 4 madde, bağlllık (B) ile ilgili 5 madde (Morgan ve Hunt, 1994), iş birliği (IS) ile ilgili 5 madde (Cannon ve Perreault Jr, 1999) ilgili çalışmalarından uyarlanmıştır. Son olarak kaynak avantajı boyutunun ölçümüne yönelik kullanılan ölçeklerde sırasıyla konum avantajı (KA) ile ilgili 5 madde (Jap, 1999), ortaklık performansı (OP) ile ilgili 7 madde (Lambe vd., 2002), üniversite performans1 (UP) ile ilgili 9 madde (Caruana vd., 1998; Caruana vd., 1999; Niculescu vd., 2013) ilgili çalışmalarından uyarlanmıştır. Çalışmada yer alan ölçek maddelerinin ölçümü için 7'li likert ölçek kullanılmıştır. Buna göre katılımcılara olumsuzdan olumluya doğru; 1- "Kesinlikle Katılmıyorum", 2-"Katılmıorum", 3-"Kısmen Katılmıorum", 4-“Kararsızım", 5-“Kısmen Katılıyorum", 6-“Kat1liyorum", 7-“Kesinlikle Katılıyorum" şeklinde cevap seçenekleri sunulmuştur. 


\section{BULGULAR}

\subsection{Demografik Özellikler}

Liste bazında silme yönetimi uygulanarak kayıp verilerden arındırılmış 513 kişilik veri seti elde edilmiştir. Katılımcıların \%60'1 (309) akademik personel, \%40'1 (204) ise idari personelden oluşmaktadır. Katılımcıların \%65'i (329) erkek, \%35'i (184) ise kadındır. Yaş dağılımları açısından değerlendirildiğinde ise 26-30 yaş grubu 90 kişi $(\% 17,5), 31-35$ yaş grubu 134 kişi $(\% 26,1), 36-40$ yaş grubu 117 kişi $(\% 22,8), 41-45$ yaş grubu 76 kişi $(\% 14,8)$, 46-50 yaş grubu 57 kişi $(\% 11,1)$, diğer yaş gruplarından katılımcıların sayısı ise $39(\% 7,6)$ dur. Katılımcıların görev yaptıkları birim açısından incelendiğinde 227 (\%44,2) kişi fakülte, $122(\% 23,8)$ katılımcı meslek yüksekokulu, $123(\% 24,0)$ kişi idari birim, $34(\% 6,6)$ kişi yüksekokul ve 7 kişi $(\% 1,4)$ enstitü şeklinde sıralanmaktadır.

\subsection{Keşfedici ve Doğrulayıcı Faktör Analizi}

Ölçeklerin güvenirlilik ve geçerliliği ile ilgili konularda geleneksel olarak ilk önce ilgili istatistiksel araçlar ile elde edilen geçerlilik ve güvenirlilik değerlerinin belirli bir çerçevede ele alınması gerekmektedir (Schumacker ve Lomax, 2015: 93). Bu çerçevede araştırma modelinin analizine geçilmeden önce araştırma modelinde bulunan ölçeklere yönelik olarak keşfedici faktör analizi (KFA) ve doğrulayıcı faktör analizi (DFA) gerçekleştirilmiştir.

Gerçekleştirilen birinci KFA sonucunda sırasıyla OK2-0,573, IL4-0,460, G3-0,434, IS50,492, UP3-0,475, UP8-0,474, UP9-0,438, OP4-0,395 ve OP5-0,424 faktör yüklerinin 0,5'ten düşük olması ve IS5 ve OK2 değişkenlerinin aynı zamanda diğer faktörler ile çapraz yüklenmesi nedeniyle analizden çıkartılarak ikinci KFA gerçekleştirilmiştir. Yapılan analiz sonrası Kaiser-Meyer-Olkin örneklem yeterliliği ölçümü (Kaiser-Meyer-Olkin Measure of Sampling Adequacy-KMO) değerinin 0,6'dan büyük olması $(0,961)$ örneklem büyüklüğünün yeterli olduğunu ve Bartlett's testi sonucunun $(\mathrm{p}<.05)$ olması sebebiyle de verilerin normal dağılıma sahip olduğu ve birim matris özelliği olmadığını göstermektedir. KMO ve Bartlett testlerinin değerlendirilmesi sonucu sahip olunan faktör analizi yapılmasının uygun olduğu sonucuna ulaşılmış ve öz değeri 1'den büyük 11 boyut tespit edilmiştir.

Tablo 1. Keşfedici Faktör Analizi

\begin{tabular}{llccc}
\hline \multirow{2}{*}{ Boyutlar } & Faktör Yükleri & $\begin{array}{c}\text { Kullanılan Madde } \\
\text { Sayısı }\end{array}$ & $\begin{array}{c}\text { Cronbach's Alfa } \\
\text { Değeri }\end{array}$ \\
\hline UYD & Üst Yönetim Desteği & $0,695-0,845$ & 5 & 0,895 \\
\hline OY & Ortaklık Yetkinliği & $0,677-0,768$ & 6 & 0,882 \\
\hline TK & Tamamlayıcı Kaynaklar & $0,649-0,711$ & 3 & 0,867 \\
\hline OK & Özgün Kaynaklar & $0,498-0,598$ & 5 & 0,852 \\
\hline IL & İletişim & $0,628-0,703$ & 3 & 0,784 \\
\hline G & Güven & $0,557-0,661$ & 4 & 0,815 \\
\hline B & Bağlılı & $0,521-0,634$ & 5 & 0,859 \\
\hline IS & İş birliği & $0,574-0,643$ & 4 & 0,827 \\
\hline KA & Konum Avantaj1 & $0,506-0,58$ & 5 & 0,852 \\
\hline UP & Üniversite Performansı & $0,478-0,636$ & 6 & 0,875 \\
\hline OP & Ortaklık Performansı & $0,545-0,592$ & 5 & 0,858 \\
\hline Toplam Açlklanan Varyans & & & $\% 67,29$ \\
\hline
\end{tabular}

Keşfedici faktör analizi sonucu ölçeklere yönelik elde edilen en küçük ve en büyük faktör yükleri ile ilgili boyutların Cronbach alfa değeri Tablo 1'de gösterildiği gibidir. Elde edilen faktör yüklerinin 0,5 değerine yakın ve üzerinde olması sebebiyle kabul edilebilir düzeyde olduğu söylenebilir (George ve Mallery, 2003: 231). 
Kullanılan boyutlarda yer alan ölçeklerin güvenirliğini ve geçerliliği sınandığı doğrulayıcı faktör analizi gerçekleştirilmiş $(\chi 2=1703,044, \quad \mathrm{df}=1169, \quad \chi 2 / \mathrm{df}=1,457, \quad \mathrm{CFI}=0,963$, AGFI=0,874, SRMR=0,0317, RMSEA=0,03, PClose=1) ve Tablo 2'de ölçüm modeline ilişkin korelasyon matrisi ile yapı güvenirliliği (CR), ortalama açıklanan varyans (AVE), maksimum paylaşılan varyansın karesi (MSV) ve MaxR değerleri gösterilmektedir. Yakınsaklık geçerliliği açısından incelendiğinde hesaplanan kompozit güvenirlik (CR) değerlerinin 0,70'ten, ortalama açıklanan varyans (AVE) değerlerinin ise 0,50'den büyük olduğu anlaşılmaktadır. Her bir boyuta ait CR değerlerinin yine bu boyutlara ait olan AVE değerlerinden büyük olduğu görülmektedir.

Iraksaklık geçerliliği açısından incelendiğinde Tablo 2'de yer alan değerlerin $\mathrm{MSV}<\mathrm{AVE}$ ve AVE'nin karekökünün faktörler arası korelasyondan büyük olması koşullarının sağladığı (Yaşlığlu, 2017: 83) görülmektedir.

Tablo 2. Korelasyon Matrisi

\begin{tabular}{lccccccccccccccc}
\hline & CR & AVE & MSV & MaxR & UP & OP & OY & UYD & B & OK & KA & G & IS & IL & TK \\
\hline UP & 0,88 & 0,54 & 0,50 & 0,88 & $\mathbf{0 , 7 3}$ & & & & & & & & & \\
OP & 0,86 & 0,55 & 0,42 & 0,86 & 0,64 & $\mathbf{0 , 7 4}$ & & & & & & & & \\
OY & 0,88 & 0,56 & 0,45 & 0,88 & 0,64 & 0,51 & $\mathbf{0 , 7 5}$ & & & & & & & \\
UYD & 0,90 & 0,63 & 0,43 & 0,90 & 0,59 & 0,52 & 0,66 & $\mathbf{0 , 8 0}$ & & & & & & \\
B & 0,86 & 0,55 & 0,42 & 0,86 & 0,54 & 0,64 & 0,47 & 0,49 & $\mathbf{0 , 7 4}$ & & & & & \\
OK & 0,85 & 0,54 & 0,52 & 0,86 & 0,71 & 0,54 & 0,67 & 0,60 & 0,53 & $\mathbf{0 , 7 3}$ & & & & \\
KA & 0,85 & 0,54 & 0,46 & 0,85 & 0,65 & 0,56 & 0,62 & 0,58 & 0,56 & 0,66 & $\mathbf{0 , 7 3}$ & & & \\
G & 0,84 & 0,57 & 0,52 & 0,85 & 0,62 & 0,60 & 0,64 & 0,60 & 0,60 & 0,72 & 0,68 & $\mathbf{0 , 7 5}$ & & & \\
IS & 0,83 & 0,55 & 0,50 & 0,83 & 0,71 & 0,65 & 0,60 & 0,54 & 0,58 & 0,67 & 0,65 & 0,70 & $\mathbf{0 , 7 4}$ & & \\
IL & 0,78 & 0,55 & 0,50 & 0,79 & 0,70 & 0,60 & 0,60 & 0,58 & 0,57 & 0,61 & 0,59 & 0,70 & 0,68 & $\mathbf{0 , 7 4}$ & \\
TK & 0,87 & 0,69 & 0,49 & 0,87 & 0,65 & 0,57 & 0,62 & 0,64 & 0,54 & 0,65 & 0,60 & 0,70 & 0,55 & 0,61 & $\mathbf{0 , 8 3}$ \\
\hline
\end{tabular}

$\mathrm{Bu}$ sonuçlar göz önünde alındığında uyum geçerliliğinin sağlandığını ifade etmek mümkündür. Doğrulayıcı faktör analizinden elde edilen değişkenlere ilişkin $t$ değerlerinin anlamlılık düzeylerinin 2,56 değerinden büyük olması gerekmektedir (Çokluk vd., 2016). Tüm $\mathrm{t}$ değerlerinin 2,56 değerinin üzerinde olması sebebiyle araştırmada yer alan tüm boyutların 0,01 düzeyinde istatistiksel anlamlılığa sahip olduğu ifade edilebilir. Son olarak ıraksaklık geçerliliğin tespiti amacıyla faktörler arasındaki ilişkiyi temsil eden korelasyon matrisi ve AVE değerlerinin karekökleri karşılaştırılmıştır. Açıklanan varyans değerlerinin karekökünün boyutlar arası korelasyon değerlerinden büyük olduğu ve böylelikle iraksaklık açısından geçerli olduğu söylenebilmektedir. Araştırma modelinde yer alan araştırma varsayımlarının incelenmesinde yol analizi için gerekli yeterliliğe sahip olmadığı incelenmiş ve elde edilen sonuçlar Tablo 3 'te gösterilmiştir. Araştırma modelinin uyum iyiliği indeksleri $(\chi 2 / \mathrm{df}=1,553, \quad \mathrm{CFI}=0,955, \quad$ AGFI $=0,955, \quad \mathrm{TLI}=0,952, \quad$ SRMR $=0,051, \quad$ RMSEA $=0,033$, PClose=1) incelendiğinde önerilen eşik değerleri (Hu ve Bentler, 1999; Schumacker ve 
Lomax, 2015) arasında bulunduğu gözlemlenmiş ve yol analizi için gerekli yeterliliğe sahip olduğu kabul edilmiştir.

Tablo 3. Araştırma Modeli Uyum İyiliği İndeksleri Sonuçları

\begin{tabular}{lcc}
\hline Uyum İndeksleri & Tahmin & Eşik Değeri \\
\hline$\chi^{2}$ & 1782,649 & - \\
$\mathrm{df}$ & 1148 & - \\
$\chi 2 / \mathrm{df}$ & 1,553 & $0 \leq \chi 2 / \mathrm{df} \leq 3$ \\
CFI & 0,955 & $0,95 \leq \mathrm{CFI} \leq 1$ \\
AGFI & 0,87 & $0,85 \leq \mathrm{AGFI}<0.90$ \\
IFI & 0,955 & $0,95 \leq \mathrm{IFI} \leq 1$ \\
TLI & 0,952 & $0,95 \leq \mathrm{TLI} \leq 1$ \\
SRMR & 0,051 & $0 \leq \mathrm{SRMR} \leq 0,08$ \\
RMSEA & 0,033 & $0 \leq \mathrm{RMSEA} \leq 0,06$ \\
PClose & 1 & $0,1<\mathrm{p} \leq 1$ \\
\hline
\end{tabular}

AMOS programı ile hesaplanan yol analizi sonuçları ve bu parametreler ile ilgili standartlaştırılmış tahmin değeri, standartlaştırılmamış tahmin değeri, standart hataları (S.E.) ve kritik değerleri (C.R.), istatistiksel anlamlılık testi sonuçları (p), Tablo 4'de gösterilmektedir. Elde edilen C.R. değerlerinin 2,086 ile 7,069 değerleri arasında bulunduğu gözlemlenmiş ve araştırma hipotezlerinin geçerliliği için gerekli olan 1,96 değerinden büyük veya eşit olma şartını sağladığı gözlemlenmektedir.

Elde edilen bulgular çerçevesinde araştırma varsayımları incelendiğinde üst yönetim desteğinin işletmelerin iş birliklerine yönelik ortaklık yetkinliğini $(\beta=0,702, p<0,001)$ olumlu etkilediği sonucu bulunmuştur. Tamamlayıcı kaynaklar açısından değerlendirildiğinde işletmenin ortaklık yetkinliği $(\beta=0,274, p<0,001)$ ve paydaşları ile sahip olduğu ilişkilerde sahip olduğu güven $(\beta=0,551, p<0,001)$ pozitif yönde bir etkiye sahiptir. Araştırma sonucuna göre ortaklık yetkinliği $(\beta=0,297, p<0,001)$, tamamlayıcı kaynaklar $(\beta=0,284, p<0,001)$ ve iş birliği $(\beta=0,377, p<0,001)$ kaynak temelli bakış açısına göre işletmelerin rekabette en değerli kaynaklarından birisi olarak ele alınan özgün kaynakları olumlu yönde etkilemektedir. Özgün kaynakların oluşturulmasında özellikle iş birliklerinin diğer faktörler ile karşılaştırıldığında daha önemli bir role sahip olduğu anlaşılmaktadır. İlişkisel pazarlamada iletişim $(\beta=0,454$, $\mathrm{p}<0,001)$ ve üst yönetim desteğinin $(\beta=0,375, p<0,001)$ güven üzerinde olumlu etkisi olduğu desteklenmiştir. Bununla birlikte güvenin de $(\beta=0,577, \mathrm{p}<0,001)$ bağlılık üzerinde olumlu etkisi olduğu varsayımı kabul edilmiştir. Araştırma modelinde önemli bir role sahip olan ilişkisel pazarlama çerçevesinde oluşturulan iş birlikleri üzerinde etkili olan faktörlere yönelik oluşturulan varsayımlar incelendiğinde; iletişim $(\beta=0,333, p<0,001)$, güven $(\beta=0,438$, $\mathrm{p}<0,001)$ ve bağlılığın $(\beta=0,15, \mathrm{p}<0,01)$ pozitif yöndeki etkisi olduğu bulgusuna ulaşılmıştır. Kaynak avantajı teorisi çerçevesinde incelenen ortaklık performansı, konum avantaj1, üniversite performansı boyutlarına yönelik sonuçlar incelendiğinde; ortaklık yetkinliği $(\beta=0,133, p<0,05)$, özgün kaynaklar $(\beta=0,083, p<0,05)$ ve konum avantajının $(\beta=0,078$, $\mathrm{p}<0,05)$ ortaklık performansı üzerinde etkisi istatistiksel olarak desteklenmemiş, iş birliğinin $(\beta=0,465, p<0,001)$ ortaklık performansı üzerindeki etkisi olduğu varsayımı kabul edilmiştir. Ortaklık yetkinliği $(\beta=0,23, p<0,001)$, özgün kaynaklar $(\beta=0,279, p<0,001)$ ve iş birliğinin $(\beta=0,353, p<0,001)$ konum avantaj1 elde edilmesinde pozitif yönde etkisi olduğu bulgusuna ulaşılmıştır. Rekabet avantajı teorisi çerçevesinde ele alınan konum avantaj1 $(\beta=0,921$, $\mathrm{p}<0,001)$ ve iş birliğinin $(\beta=0,162, \mathrm{p}<0,01)$ üniversite performansı üzerinde olumlu etkiye sahip olduğu bulgusuna ulaşılmıştır. Son olarak ise üst yönetim desteği ile iletişim arasında $(\beta=0,615, p<0,001)$ karşılıklı bir ilişki olduğu sonucu elde edilmiştir. 
Tablo 4. Araştırma Modeli Yol Analizi ve Hipotez Testleri

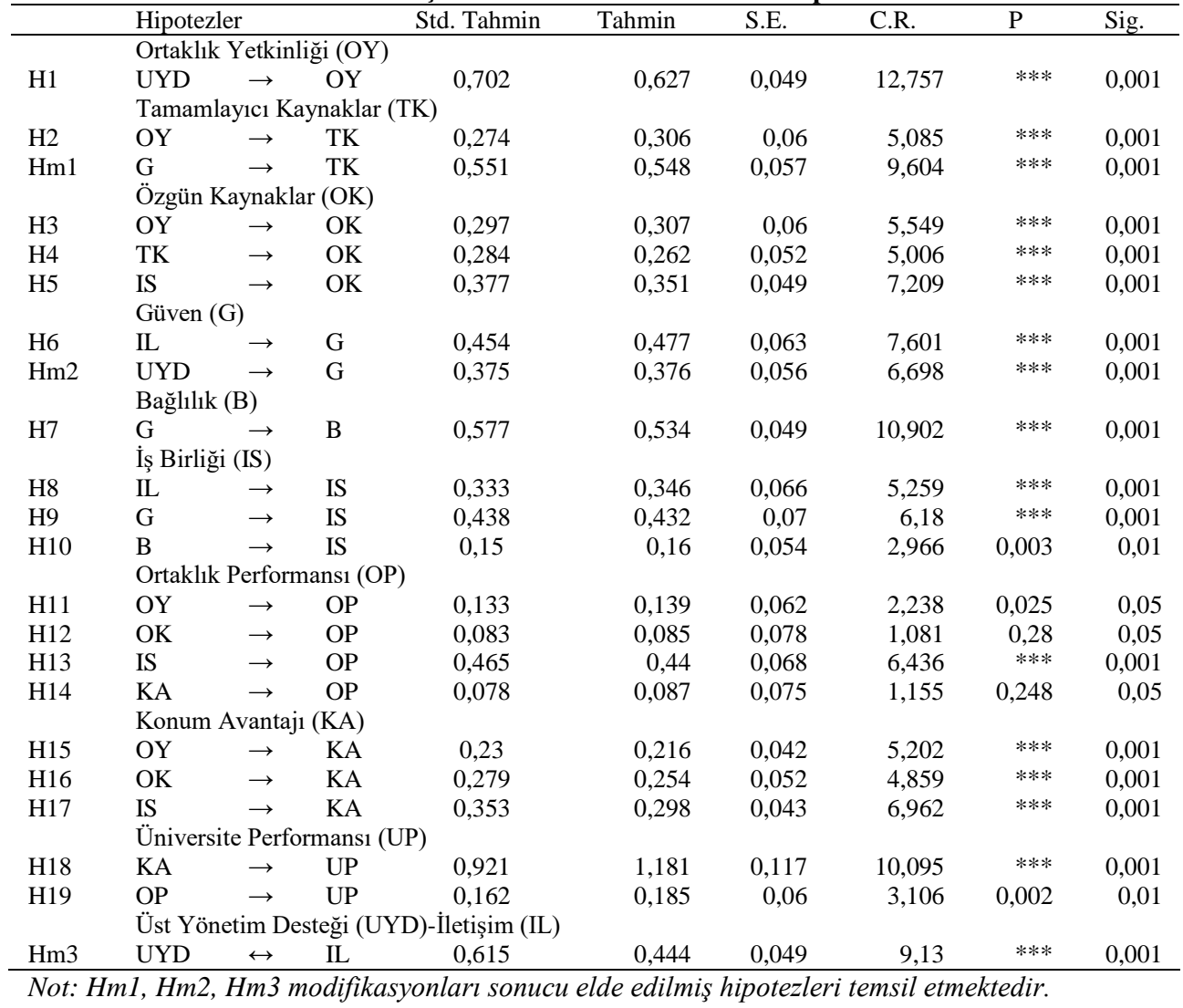

Özetle elde edilen veriler bağlamında oluşturulan H13 ve H18 hipotezleri 0,05 istatistiksel önem düzeyinde anlamlı bulunmadığı bu sebeple araştırma varsayımının desteklenmediği görülmektedir. Araştırma modeli çerçevesinde modifikasyon sonrası elde edilen hipotezler olan Hm1, Hm2 ve Hm3 ile diğer hipotezler 0,05 anlamlılık düzeyinde anlamlı bulunmuş ve istatistiksel olarak desteklendiği sonucuna ulaşılmıştır.

\section{SONUÇ}

Yükseköğretim kurumlarını post endüstriyel toplumunun en temel kurumlarından birisidir (Bell, 1973: 20). Günümüzde yükseköğretim kurumlarının temel amaçlarından bir tanesinin de üstün performans göstermek ve ürettikleri değerin maliyetlerine oranla rakiplerinden düşük olması gerektiği düşünülmektedir (Goh, 2003: 98). Bu yaklaşımın temeli yeni kamu yönetimi düşüncesi çerçevesinde gelişmiştir. Özellikle hesap verilebilirlik ilkesinin ön plana çıkmaya başlaması ile vatandaşlardan alınan vergiler ile finanse edilen yükseköğretim kurumlarının günümüzde çıktı odaklı bütçeleme uygulamaları tartışılmaya ve uygulanmaya başlanmıştır. Üstün finansal performans ile işletme başarı performansının ölçülmeye çalışıldığı amaçlanmakta olduğu literatürde yer almaktadır. Buna göre finansal performans, karlılık, yatırım getirisi gibi belli başlı göstergelerin önemi işletmeden işletmeye, endüstriden endüstriye ve ülkeden ülkeye değişiklik gösterebilmektedir (Hunt ve Morgan, 1997: 78; 
Arnett ve Hunt, 2002: 281; Hunt ve Morgan, 2004: 172). Arnett vd. (2003)'e göre ilişkisel pazarlama yükseköğretim kurumlarına uygulanabilir özelliğe sahiptir, fakat kar amaçsız organizasyonlar için ekonomik başarı tek başarı faktörü olmadığı gibi bunun yanı sıra duygusal tatmin ile sosyal fayda, manevi değer ile insani amaçların paylaşılması gerektiğine de vurgu yapmışlardır. Bu kapsamda düşük maliyetle daha yüksek değer üretebilen yükseköğretim kurumlarının üstün finansal performans elde ettiği ve böylelikle rakipleri karşısında pazar rekabet konumlarında karşılaştırmalı üstünlük elde edebileceklerine vurguda bulunmaktadır. Kaynak avantajı teorisi kapsamında Şahin ve Taşkın (2014) tarafından Türkiye'deki kamu yükseköğretim kurumlarının bütçeleri ve bağıl çıktıları temel alınarak pazar konumları tespit edilmeye çalışılmıştır.

Birçok endüstride stratejik iş birlikleri ve ilişki ağları gibi yapıları da kapsayan yeni örgüt yapıları ortaya çıkmaya başlamış ve basit pazar temelli değişime odaklı, geleneksel, bürokratik hiyerarşi çerçevesinde yapılanmış örgütlerin yerini almaya başlamıştır (Webster, 1992: 1). Günümüz küresel ekonomisinde etkili bir rakip olabilmek için en azından bazı ilişki ağları içerisinde güvenilir bir işletme olmak bir gereklilik halini almıştır (Morgan ve Hunt, 1994: 20). Kaynak avantajı teorisinin incelenmesine yönelik Wittmann vd. (2009) tarafindan iki kâr amacı güden işletme arasındaki iş birliği çerçevesinde yürütülen araştırmada; ortaklık yetkinliğinin özgün kaynak üzerindeki etkisi ile iletişimin iş birliği üzerindeki etkileri araştırma sonucunda desteklenmemiştir. Ulaşılan sonucun ilgili literatürü desteklemediği fakat (Morgan ve Hunt, 1994)'ın da dikkat çektiği üzere birçok iş birliği çeşidi bulunması nedeniyle bu araştırma modelinin farklı iş birlikleri çerçevesinde uygulanmasının önemli olduğunu öne sürmüşlerdir.

Bu kapsamda gerçekleştirilen araştırmanın bulgularını Wittmann vd. (2009)'ın bulguları ile karşılaştırdığımızda ilişkisel pazarlama kapsamında iş birliklerinin oluşturulmasında sırasıyla, güven, iletişim ve bağlılığın önemli faktörler olduğu desteklenmiştir. Özellikle ilişkisel pazarlama kapsamında işletmelerin paydaşları ile geliştirdikleri iş birliklerinin özgün kaynak oluşturma kabiliyetlerine, konum avantajı elde edebilmelerine ve ortaklık performansı üzerine pozitif yönde etkileri sebebiyle önem taşımaktadır. Bu özgün kaynakların geliştirilmesi amacıyla oluşturulacak olan iş birliklerinde tamamlayıcı kaynaklara sahip olmanın ve bu iş birliğini geliştirecek üst yönetim tarafından desteklenen ortaklık yetkinliğine sahip olunmasının da önemli olduğu sonucuna ulaşılmıştır. Üst yönetim desteği iş birliği ortaklıklarının geliştirilmesinde ve ayrıca ilişkisel pazarlamada güvenin tesisinde de önemli bir rol oynamaktadır. İlişkisel pazarlama kapsamında güvenin geliştirilmesi iş birliği içerisindeki paydaşların tamamlayıcı kaynakları ilişki içerisine taşıma istekliliğini de arttırmakta olduğu sonucuna ulaşılmıştır. İş birliği oluşturmada üst yönetim desteğinin ayrıca iletişim ile doğru yönde bir ilişkiye sahip olduğu bulgusuna ulaşılması; iletişim faaliyetlerinin arttıkça üst yönetim desteğinin arttığı ve ayrıca üst yönetim desteğinin arttıkça iletişim çabalarının da artması gerektiğini sonucuna ulaşılmıştır. Araştırma bulguları çerçevesinde yükseköğretim kurumlarının konum avantajı elde edebilmelerinde önem sırasına göre; ilişkisel pazarlama kapsamında paydaşları arasında tesis ettikleri iş birliği kurma eğilimleri, özgün kaynak elde edilmesi ve iş birliği kurmaya yönelik sahip olunan ortaklık yetkinlikleri önemli rol oynamaktadır. Yükseköğretim kurumlarının iş birliği ortaklık performanslarının arttırılmasında kurumun ortaklık yetkinlikleri ve ilişkisel pazarlama kapsamında sahip olunan ilişki portföyünde yer alan paydaşların iş birliği yapma niyetlerinin de pozitif yönlü bir etkiye sahip olduğu sonucuna ulaşılmıştır. Yükseköğretim kurumu performansını arttırmada ön 
plana çıkan faktör konum avantajı olurken daha sonra ortaklık performansının da pozitif yönlü bir etkisi olduğu bulgular arasında yer almaktadır.

Araştırma sonuçları çerçevesinde görülmektedir ki yükseköğretim kurumlarının da günümüzde pazarlama faaliyetleri gerçekleştirilmesi kaçınılmaz bir hale gelmeye başlamaktadır. Özellikle kamu yükseköğretim kurumlarının devlet bütçesinden finanse edilmesi ve bu kaynakların etkin, etkili ve verimli kullanılması beklentisi yeni kamu yönetim uygulamaları çerçevesinde uygulanmaya başlanması ile daha da artmıştır. Yükseköğretim kurumlarının paydaşları ile ilişkiler kurması, geliştirmesi, sürdürmesi ve bu ilişkilerde yer alan stratejik paydaşlar ile iş birlikleri kurabilmelerinde güven, bağlllık ve üst yönetim tarafından desteklenmiş iletişim çabalarının arttırılması gerekmektedir. $\mathrm{Bu}$ kapsamda yükseköğretim kurumlarının stratejik paydaşlarının yer aldığ 1 bir portföy oluşturarak düzenli bir şekilde analizlerini gerçekleştirmesi avantajlı gördüğü ilişkileri uzun vadede geliştirmeye yönelik çaba sarf etmelidirler. Kaynak temelli bakış açısı ile yaklaşıldığında ise yükseköğretim kurumlarının oluşturdukları iş birliklerine paydaşların tamamlayıcı kaynakları getirmesini teşvik ederek bu iş birlikleri kapsamında rakiplerine karşı avantaj sağlamada kilit role sahip olan özgün kaynakların geliştirilmesi amacıyla kurum ortaklık yetkinliklerini geliştirmeli ve paydaşlar ile ilişkilerinde güven sağlamalıdırlar. Yükseköğretim kurumlarının üst yönetimleri stratejik paydaşlar ile iş birliği ortaklığı kurabilme yetkinlikleri geliştirmeleri için desteklemeli; kurdukları işbirliklerinde yer alan taraflar ile özgün kaynaklar oluşturabilmeleri için tamamlayıcı kaynakların iş birliğine getirilmesini teşvik etmek için çaba sarf etmeleri; stratejik paydaşlarını belirleyerek bu paydaşlar ile iletişim, güven ve bağlllık çerçevesinde uzun dönemli ilişkiler geliştirerek paydaşları yükseköğretim kurumları ile işbirlikleri kurmaya yönlendirebilmelidirler. Yükseköğretim kurumlarının uzun dönemli paydaşlarının ilişkisel pazarlama kapsamında iş birliği yapma istekliliklerinin arttırılması, üst yönetim tarafindan bu yönde kurumsal yetkinliklerin geliştirilmesinin desteklenmesi rekabette onları diğerlerinden farklılaştıracak özgün kaynaklara sahip olabilmelerini mümkün kılarak hem diğer rakiplerine kıyasla pazar da konum avantajı elde edebilmelerini hem de kurum performanslarını arttıracaktır. Her ne kadar geçmişte yükseköğretim kurumlarının pazarlama faaliyetlerini kullanmalarının bazı etik sorunlara neden olup olmayacağı tartışma konusu olsa da günümüzde bir zorunluluk halini almıştır. Bu araştırmada da pazarlama faaliyetlerin uzun dönemli ilişkiler çerçevesinde yürütülmesi ile yükseköğretim kurumlarının performans çıktılarının nasıl arttırılabileceği kaynak avantajı teorisi çerçevesinde açıklanmıştır. Küreselleşme ile hem araştırma geliştirme faaliyetleri ve bu faaliyetlerden elde edilebilecek finansman hem de ögrencilerin tercih oranlarını kurum lehine arttırmaya çalışmakta oldukları dolayısıyla bu ve buna benzer alanlardaki rekabetin giderek yoğunlaştığı çevrede pazarlama faaliyetlerinin önemli bir rol oynadığı düşünülmektedir.

Sonuç olarak yükseköğretim kurumlarının daha nitelikli öğrenci ve akademik personel ile finansal kaynaklara ulaşabilmek için sahip oldukları ilişki portföylerini etkin bir şekilde yönetebilmeleri ve pazarlama faaliyetleri önem kazanmaya başlamıştır. Bu açıdan yükseköğretim kurumları sahip oldukları paydaşları iyi bir şekilde analiz ederek stratejik ilişki portföyleri oluşturmaları ve bunları iyi bir şekilde yönetebilmeleri, pazar konumlarında rekabet avantaj1 elde edebilmelerini ve böylelikle kurum performanslarını en üst düzeye çıkartabilmelerini sağlayacak olan kaynaklara ulaşabilmelerini sağlayabilecektir. 


\section{Araştırmanın kısıtları}

$\mathrm{Bu}$ araştırmanın yürütülmesinde tüm katılımcıların konu ile ilgili tam bilgiye sahip olduğu ilgili literatür göz önüne alınarak varsayılmış ve bilgi düzeyleri sorgulanmamıştır. Araştırmada kullanılan veriler iş birliği içerisindeki bir taraf olan UÜ’'den elde edilmiş diğer paydaşların görüşlerine yer verilmemiştir. Araştırma kapsamında iş birliği içerisindeki paydaşların bu iş birliğinden eşit şekilde fayda sağladıkları düşünülmüştür. Konu ile ilgili olarak gelecekte yürütülecek olan çalışmalarda katılımcıların bilgi düzeyleri arasındaki farklılıkların da araştırmaya dahil edilmesi; iş birliği içerisinde yer alan tüm paydaşların araştırmaya dahil edilerek elde ettikleri kaynaklar ile çıktıların karşılaştırılması ile ortakların iş birliğinden elde ettikleri değer farklılaşmasının değerlendirilmesinin önemli olduğu düşünülmektedir. $\mathrm{Bu}$ araştırmada iş birliği ve kurum performansı/başarısını etkileyen diğer temel kaynaklar incelenmemiştir. Finansal, yasal, fiziksel, insan, örgütsel, ilişkisel ve bilgi (Hunt ve Morgan, 1995) gibi diğer kaynakların tek başlarına ve birbirleri ile etkileşim halinde rekabet üzerindeki etkileri incelenmemiş olması sebebiyle gelecekteki araştırmaların bu çeşitli kaynakların ve/veya kombinasyonlarının rekabet avantajı elde edilmesindeki rolleri ve böylelikle işletme ve iş birliği performansı dolayısıyla başarısı üzerindeki etkilerinin incelenmesinin önemli olduğu düşünülmektedir. Son olarak özellikle yükseköğretim kurumlarının pazarlanmasına yönelik araştırmaların kısıtlı olması sebebiyle bu alanda gerçekleştirilecek çalışmaların ilgili yazına önemli katkılar sağlayacağı düşünülmektedir.

\section{KAYNAKÇA}

A.A. (2016). "Yök Başkanı Prof. Dr. Saraç: Yükseköğretimde Taşlar Yerinden Oynadı", Retrieved from http://aa.com.tr/tr/egitim/yok-baskani-prof-dr-sarac-yuksekogretimdetaslar-yerinden-oynadi/713682?amp=1, 26.12.2016.

ACHROL, R. S., ve STERN, L. W. (1988). "Environmental Determinants of DecisionMaking Uncertainty in Marketing Channels", Journal of Marketing Research (JMR), 25(1): 36-50.

AHUJA, G. (2000). "The Duality of Collaboration: Inducements and Opportunities in the Formation of Interfirm Linkages", Strategic Management Journal, 21(3): 317-343.

ARIMOTO, A. (2014). "The Teaching and Research Nexus in the Third Wave Age", J. C. Shin, et al. (eds.), Teaching and Research in Contemporary Higher Education (15-33), Springer, Dordrecht.

ARNETT, D. B., GERMAN, S. D., ve HUNT, S. D. (2003). "The Identity Salience Model of Relationship Marketing Success : The Case of Nonprofit Marketing", Journal of marketing, 67(2): 89-105.

ARNETT, D. B., ve HUNT, S. D. (2002). "Competitive Irrationality: The Influence of Moral Philosophy", Business Ethics Quarterly, 12(03): 279-303.

BARNEY, J. (1991). "Firm Resources and Sustained Competitive Advantage", Journal of management, 17(1): 99-120.

BARNEY, J. B. (1992). "Integrating Organizational Behavior and Strategy Formulation Research: A Resource Based Analysis", Advances in strategic management, 8(1): 3961. 
BELL, D. (1973). "The Coming of Post-Industrial Society a Venture in Social Forecasting ", Basic Books Inc. Publishers, New York.

BOLES, J., BRASHEAR, T., BELLENGER, D., ve BARKSDALE JR, H. (2000). "Relationship Selling Behaviors: Antecedents and Relationship with Performance", Journal of Business \& Industrial Marketing, 15(2/3): 141-153.

CANNON, J. P., ve PERREAULT JR, W. D. (1999). "Buyer-Seller Relationships in Business Markets", Journal of marketing research, 36(4): 439-460.

CARUANA, A., RAMASESHAN, B., ve EWING, M. T. (1999). "Market Orientation and Performance in the Public Sector: The Role of Organizational Commitment", Journal of Global Marketing, 12(3): 59-79.

CARUANA, A., RAMASESHAN, B. Y., ve EWING, M. T. (1998). "Do Universities That Are More Market Orientated Perform Better?", International journal of public sector management, 11(1): 55-70.

COLEMAN, J. S. (1988). "Social Capital in the Creation of Human Capital", American journal of sociology, 94: 95-120.

DAY, G. S. (2000). "Managing Market Relationships", Journal of the academy of Marketing Science, 28(1): 24-30.

DUDERSTADT, J. J. (2000). "A University for the 21st Century ", University of Michigan Press, Michigan, Ann Arbor.

ENDERS, J. (2006). "The Academic Profession", J. J. Forest \& P. G. Altbach (eds.), International Handbook of Higher Education, (Vol. 18), (5-22), Springer.

FALKENBERG, A. W. (1996). "Marketing and the Wealth of Firms", Journal of Macromarketing, 16(1): 4-24.

FIALOVÁ, H. (2014). Tertiary Sector Analysis in the Eu Countries. Paper presented at the Proceedings in EIIC-The 3rd Electronic International Interdisciplinary Conference.

FOURASTIÉ, J. (1949). "Le Grand Espoir Du Xxe Siècle: Progrès Technique, Progrès Économique, Progrès Social ", Presses universitaires de France.

GEORGE, D., ve MALLERY, P. (2003). "Spss for Windows Step by Step: A Simple Guide and Reference (Vol. 10/e)", Pearson Education India.

GOH, J. W. P. (2003). "The Resource Advantage Theory of Competition: Implications for Higher Educational Institutions in Singapore", Educational Research for Policy and Practice, 2(2): 93-106.

GRÖNROOS, C. (1994). "From Marketing Mix to Relationship Marketing", MANAGEMENT DECISION, 32(2): 4-20.

HAMEL, G., ve PRAHALAD, C. K. (1994). "Competing for the Future ", Harvard Business School Press, Boston, Massachusetts.

HU, L.-T., ve BENTLER, P. M. (1999). "Cutoff Criteria for Fit Indexes in Covariance Structure Analysis: Conventional Criteria Versus New Alternatives", Structural equation modeling: a multidisciplinary journal, 6(1): 1-55. 
HUNT, S. D. (1995). "The Resource-Advantage Theory of Competition toward Explaining Productivity and Economic Growth", Journal of Management Inquiry, 4(4): 317-332.

HUNT, S. D. (1997a). "Competing through Relationships: Grounding Relationship Marketing in Resource-Advantage Theory", Journal of Marketing Management, 13(5): 431-445.

HUNT, S. D. (1997b). "Evolutionary Economics, Endogenous Growth Models, and Resource-Advantage Theory", Eastern Economic Journal, 23(4): 425-439.

HUNT, S. D. (1997c). "Resource-Advantage Theory: An Evolutionary Theory of Competitive Firm Behavior?", Journal of Economic Issues, 31(1): 59-78.

HUNT, S. D. (2000). "A General Theory of Competition: Resources, Competences, Productivity, Economic Growth", Sage Publications, Thousand Oaks, California.

HUNT, S. D., ve ARNETT, D. B. (2001). "Competition as an Evolutionary Process and Antitrust Policy", Journal of Public Policy \& Marketing, 20(1): 15-26.

HUNT, S. D., ARNETT, D. B., ve MADHAVARAM, S. (2006). "The Explanatory Foundations of Relationship Marketing Theory", Journal of Business \& Industrial Marketing, 21(2): 72-87.

HUNT, S. D., ve DEROZIER, C. (2004). "The Normative Imperatives of Business and Marketing Strategy: Grounding Strategy in Resource-Advantage Theory", Journal of Business \& Industrial Marketing, 19(1): 5-22.

HUNT, S. D., ve DUHAN, D. F. (2002). "Competition in the Third Millennium: Efficiency or Effectiveness?", Journal of Business Research, 55(2): 97-102.

HUNT, S. D., ve LAMBE, C. (2000). "Marketing's Contribution to Business Strategy: Market Orientation, Relationship Marketing and Resource-Advantage Theory", International Journal of Management, 2(1): 17-43.

HUNT, S. D., LAMBE, C. J., ve WITTMANN, C. M. (2002). "A Theory and Model of Business Alliance Success", Journal of Relationship Marketing, 1(1): 17-35.

HUNT, S. D., ve MORGAN, R. M. (1995). "The Comparative Advantage Theory of Competition", Journal of marketing, 59(2): 1-15.

HUNT, S. D., ve MORGAN, R. M. (1996). "The Resource-Advantage Theory of Competition: Dynamics, Path Dependencies, and Evolutionary Dimensions", The Journal of marketing, 60: 107-114.

HUNT, S. D., ve MORGAN, R. M. (1997). "Resource-Advantage Theory: A Snake Swallowing Its Tail or a General Theory of Competition?", Journal of marketing, 61(4): 74-82.

HUNT, S. D., ve MORGAN, R. M. (2004). "The Resource-Advantage Theory of Competition: A Review", N. K. Malhotra (Ed.), Review of Marketing Research (153207), M.E. Sharpe, London, England.

JAP, S. D. (1999). "Pie-Expansion Efforts: Collaboration Processes in Buyer-Supplier Relationships", Journal of Marketing Research (JMR), 36(4): 461-475. 
JAP, S. D. (2001). "The Strategic Role of the Salesforce in Developing Customer Satisfaction across the Relationship Lifecycle", Journal of Personal Selling \& Sales Management, 21(2): 95-108.

KALE, P., SINGH, H., ve PERLMUTTER, H. (2000). "Learning and Protection of Proprietary Assets in Strategic Alliances: Building Relational Capital", Strategic management journal, 21(3): 217-237.

KALKıNMA, B. (2015). "Türkiye Girişimcilik Stratejisi ve Eylem Planı 2015-2018".

KALWANI, M. U., ve NARAYANDAS, N. (1995). "Long-Term Manufacturer-Supplier Relationships: Do They Pay Off for Supplier Firms?", Journal of marketing, 59(1): 116.

KUMAR, N., STERN, L. W., ve ACHROL, R. S. (1992). "Assessing Reseller Performance from the Perspective of the Supplier", Journal of Marketing Research (JMR), 29(2): 238-253.

LADO, A. A., BOYD, N. G., ve WRIGHT, P. (1992). "A Competency-Based Model of Sustainable Competitive Advantage: Toward a Conceptual Integration", Journal of management, 18(1): 77-91.

LAMBE, C. J., SPEKMAN, R. E., ve HUNT, S. D. (2002). "Alliance Competence, Resources, and Alliance Success: Conceptualization, Measurement, and Initial Test", Journal of the academy of Marketing Science, 30(2): 141-158.

LEWIS, M. A., ve GREGORY, M. J. (1996). "Developing and Applying a Process Approach to Competence Analysis", R. Sanchez \& A. Heene (eds.), Dynamics of CompetenceBased Competition (141-164), Pergamon, Oxford, UK.

MASUDA, Y. (1980). "The Information Society as Post-Industrial Society ", World Future Society, Washington, D.C.

MORGAN, R. M., ve HUNT, S. D. (1994). "The Commitment-Trust Theory of Relationship Marketing", Journal of marketing, 58(3): 20-38.

NICUlESCU, M., XU, B., HAMPTON, G. M., ve PETERSON, R. T. (2013). "Market Orientation and Its Measurement in Universities", Administrative Issues Journal: Education, Practice, and Research, 3(2): 75-85.

OECD. (2011). "Actor Brief: Higher Education Institutes (HEIs)", http://www.oecd.org/innovation/policyplatform/, 12.12.2016.

OECD. (2015). "Oecd Digital Economy Outlook 2015 ", OECD Publishing, Paris.

PARVATIYAR, A., ve SHETH, J. N. (1992). "Paradigm Shift in Interfirm Marketing Relationships: Emerging Research Issues", Emory University, Atlanta, GA.

PRAHALAD, C. K., ve HAMEL, G. (1990). "The Core Competence of the Corporation", Harvard Business Review, May-June, 79-91.

RUMELT, R. (1984). "Towards a Strategic Theory of the Firm", R. Lamb (eds.), Competitive Strategic Management, (556-570), Prentice Hall, Englewood Cliffs. 
SANCHEZ, R., HEENE, A., ve THOMAS, H. (1996). "Dynamics of Competence-Based Competition: Theory and Practice in the New Strategic Management ", Pergamon.

SARKAR, M. B., ECHAMBADI, R., ve HARRISON, J. S. (2001). "Alliance Entrepreneurship and Firm Market Performance", Strategic Management Journal, 22(6-7): 701-711.

SCHELlHASE, R., HARDOCK, P., ve OHLWEIN, M. (2000). "Customer Satisfaction in Business-to-Business Marketing: The Case of Retail Organizations and Their Suppliers", Journal of Business \& Industrial Marketing, 15(2/3): 106-121.

SCHUMACKER, R. E., ve LOMAX, R. G. (2015). "A Beginner's Guide to Structural Equation Modeling (4th Ed.)", Routledge Academic, Third Avenue, New York.

SCOTT, J. C. (2006). "The Mission of the University: Medieval to Postmodern Transformations", The Journal of Higher Education, 77(1): 1-39.

SELNES, F., ve SALLIS, J. (2003). "Promoting Relationship Learning", Journal of Marketing, 67(3): 80-95.

SELZNICK, P. (1957). "Leadership in Administration", Harper \& Row, New York.

SHAKER, T. I., ve BASEM, Y. A. (2010). "Relationship Marketing and Organizational Performance Indicators", European Journal of Social Sciences, 12(4): 545-557.

SHANI, D., ve CHALASANI, S. (1992). "Exploiting Niches Using Relationship Marketing", Journal of Services Marketing, 9(3): 33-42.

SHETH, J. N., ve PARVATIYAR, A. (1995). "The Evolution of Relationship Marketing", International Business Review, 4: 397-418.

SIEMENS, G., ve MATHEOS, K. (2012). "Systemic Changes in Higher Education", in Education, 16(1): 1-9.

SMITH, J. B., ve BARCLAY, D. W. (1997). "The Effects of Organizational Differences and Trust on the Effectiveness of Selling Partner Relationships", the Journal of Marketing, 61(1): 3-21.

SOLOMON, R. C. (1992). "Ethics and Excellence ", Oxford University Press, Oxford.

ŞAHIN, F., ve TAŞKIN, E. (2014). Resource-Advantage (R-a) Theory of Competition: Implication of Public Higher Education Institutions in Turkey. Paper presented at the Conference: International Conference on Quality in Higher Education (ICQH), Sakarya.

ŞAHIN, F., ve TAŞKIN, E. (2018). "Yükseköğretimde İlişkisel Pazarlama: Kaynak Avantaj1 Rekabet Teorisi (1. Bask1 ed.)", Ekin Yayınevi, Ankara.

UNESCO. (1998). World Conference on Higher Education in the Twenty-First Century Final Report. Paper presented at the World Conference on Higher Education, Paris.

VERHOEF, P. C. (2003). "Understanding the Effect of Customer Relationship Management Efforts on Customer Retention and Customer Share Development", Journal of marketing, 67(4): 30-45. 
WALTER, A., ve GEMÜNDEN, H. G. (2000). "Bridging the Gap between Suppliers and Customers through Relationship Promoters: Theoretical Considerations and Empirical Results", Journal of Business \& Industrial Marketing, 15(2/3): 86-105.

WEBER, J. A. (2000). "Partnering with Distributors to Stimulate Sales: A Case Study", Journal of Business \& Industrial Marketing, 15(2/3): 154-162.

WEBSTER, F. E. (1992). "The Changing Role of Marketing in the Corporation.", Journal of Marketing, 56: 1-17.

WISSEMA, J. G. (2009). "Towards the Third Generation University: Managing the University in Transition", Edward Elgar Publishing, Cheltenham, UK.

WITTMANN, C. M., HUNT, S. D., ve ARNETT, D. B. (2009). "Explaining Alliance Success: Competences, Resources, Relational Factors, and Resource-Advantage Theory", Industrial Marketing Management, 38(7): 743-756.

YALÇı1N, B. (2010). "Kaynak Avantajı Kuramı Üzerine Kavramsal Bir Bakış", Business \& Economics Research Journal, 1(2): 63-71.

YÖK. (2015). "Yükseköğretim Kurulu'nun 2016-2020 Stratejik Planı ", YÖK, Ankara.

YÖK. (2016). Bölgesel Kalkınma Odaklı Misyon Farklılaşması ve İhtisaslaşması Projesi Kapsamında Pilot Yükseköğretim Kurumları Belirlendi. Retrieved from http://yok.gov.tr/web/guest/ihtisaslasma-ve-bolgesel-kalkinma-belirlenen-5-universite, 17.01.2017. 